\title{
Office of River Protection Hanford Tank Waste Treatment Alternatives
}

Prepared for the U.S. Department of Energy

Assistant Secretary for Environmental Management

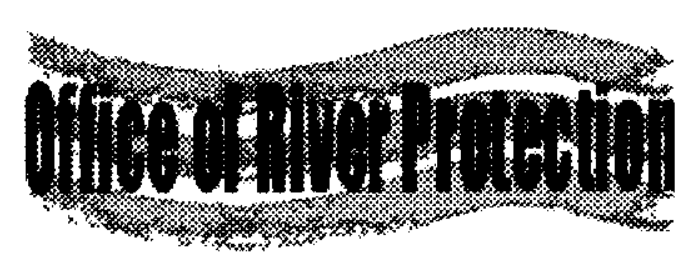

P.O. Box 450

Richland, Washington 99352 


\section{Office of River Protection Hanford Tank Waste Treatment Alternatives}

Date Published

March 2000

Prepared for the U.S. Department of Energy

Assistant Secretary for Environmental Management

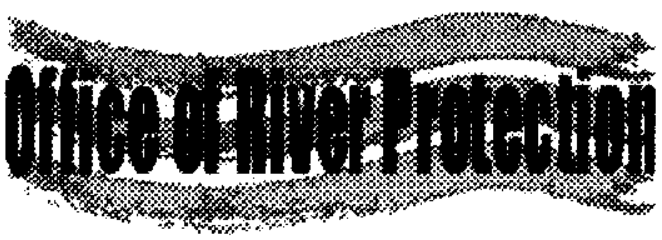

P.O. Box 450

Richland, Washington 99352 


\title{
LEGAL DISCLAIMER
}

\begin{abstract}
This report was prepared as an account of work sponsored by an agency of the United States Government. Neither the United States Government nor any agency thereof, nor any of their employees, nor any of their contractors, subcontractors or their employees, makes any warranty, express or implied, or assumes any legal liability or responsibility for the accuracy, completeness, or any third party's use or the results of such use of any information, apparatus, product, or process disclosed, or represents that its use would not infringe privately owned rights. Reference herein to any specific commercial product, process, or service by trade name, trademark, manufacturer, or otherwise, does not necessarily constitute or imply its endorsement, recommendation, or favoring by the United States Government or any agency thereof or its contractors or subcontractors. The views and opinions of authors expressed herein do nat necessarily state or reflect those of the United States Government or any agency thereof.
\end{abstract}

This report has been reproduced from the best available copy. 


\section{INFORMATION CLEARANCE FORM}

\begin{tabular}{|cc|}
\multicolumn{2}{c|}{ A. Infomation Category } \\
$\square$ Abstract & $\square$ Joumal Article \\
$\square$ Summary & $\square$ Intemet \\
$\square$ Visual Aid & $\square$ Sotwate \\
$\square$ Full Paper & $\square$ Report \\
$\square$ Other
\end{tabular}
B. Document Number DOE/ORP-2000-04
D. Titleces of fines protection

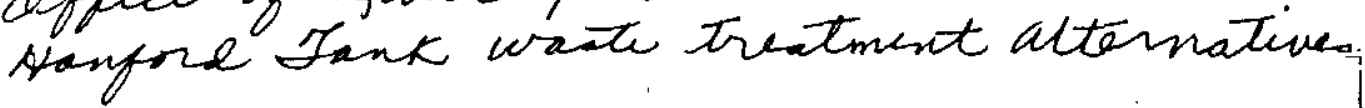
D. Internet Address

\section{E. Required Information}

1. Is document potentially classified? (DFío OYes (MANDATORY)

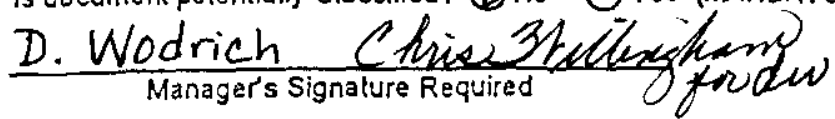

If Yes ADC Signalure Required

2. Internal Review Required? If Yes, Document Signatures Below ONo OYes classified Counsel Program

3. References in the information are Applied Technology (DNo OYes Export Controlled Intormation Q Wro OYes QNo OYes

F. Complete for a Journal Article

If Yes UC-

7. Charge Code
4. Does information Contain the Following: (MANDATORY)

a. Now or Novol (Palentublo) subject Matren (D)o OYes

If "Yes", Disclosure No.:

b. Informs jon Recowod in Confidence, Such as Proprietary and/or Inventions? (1) Ko OYes It "Yes",ATix Appropriale Logends/Notices.

c. Copyrights? (DNo OYes U"Yos", Atach Pormission.

d. Trademarks? (DNo OYes II"Yes", Identify in Document

5. Is information requiting submission to OST1? $\quad($ No $O$ Yes and $B \& R-$

6. Release Level? (D) Fublic $O$ limited

1. Title of Journal

\section{G. Complete for a Presentation}

1. Title for Conference or Meeting

2. Group Sponsoring

3. Date of Conference

4. City/State

5. Will Information be Published in Proceedings? $O$ No OYes

6. Will Material be Handed Out? O No OYes

H. Author/Requestor

D. Wodrich: (Print and Sign)

(Thie 3rallengthere)

I. Revlewers

In $\operatorname{sen} 3-24-00$ Responsible Manager

D. Wodrich (Print and Sign)

Chivi
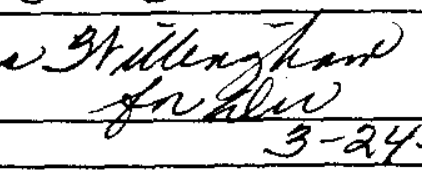

Signature

Public $Y / N$ (II $N$, complete $J)$

General Counsel

Yes Pint

$Y / N$

Office of Extemal Alfairs

DOE-RL

$\square$

.

$Y / N$

$Y / N$

Other

$\square$

.

Other

$\square$

$Y / N$.

$Y / N$

J. If Information inciudes Sensitive information and is nol to be released to the Public indicate calegory below.

$\square$ Applied Technology $\square$ Proleded CRAOA

$\square$ personaverivate $\square$ Export Controlied

$\square$ Proprielary $\square$ procurement-Sensitive

$\square$ Business-Sensitive $\square$ patenlable

$\square$ Predecisional $\square$ other (specity)

DUCNI Bu defwete thi document is approvel

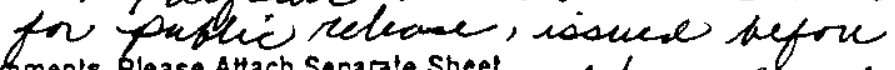

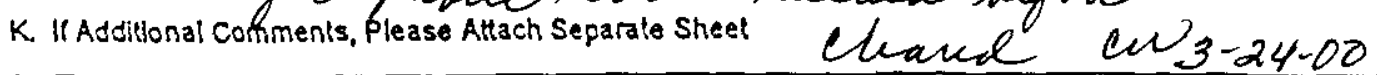




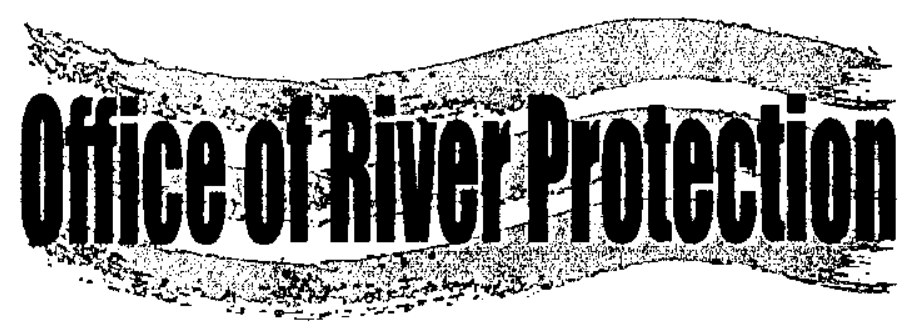

\section{Hanford Tank Waste Treatment Alternatives}

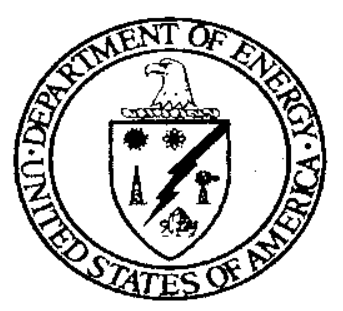




\title{
Hanford Tank Waste Processing Alternatives
}

\author{
March 2000
}

Prepared by

M.B. Triplett, Pacific Northwest National Laboratory

D.D. Wodrich, U.S. Department of Energy, Office of River Protection

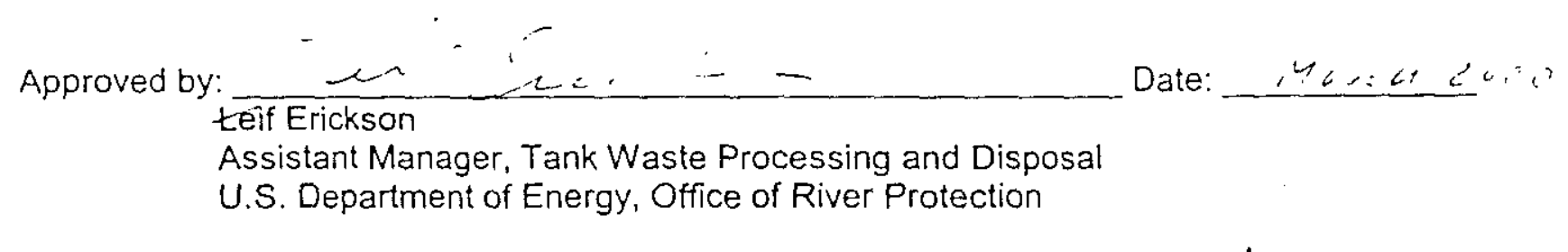




\section{Table of Contents}

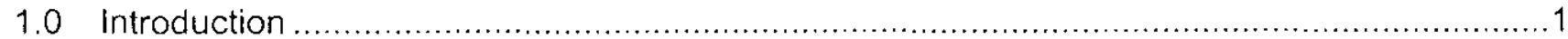

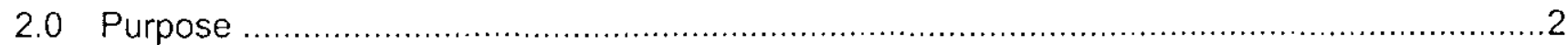

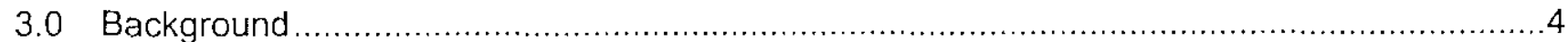

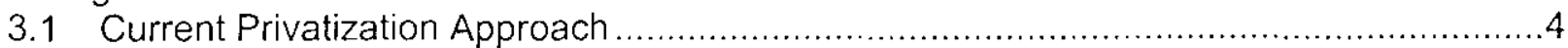

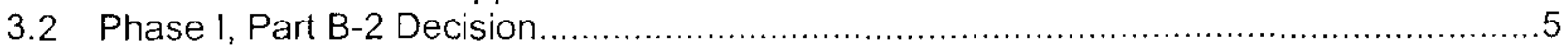

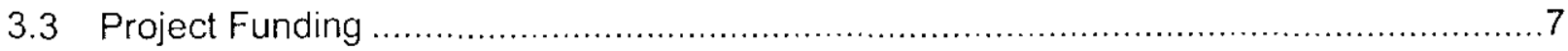

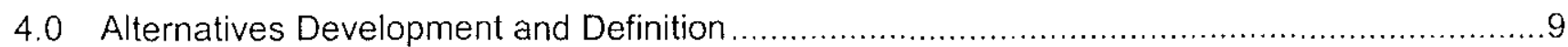

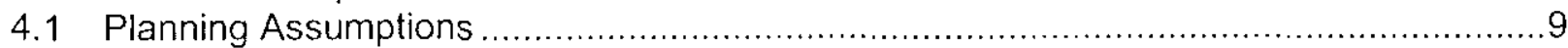

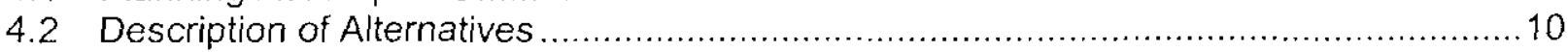

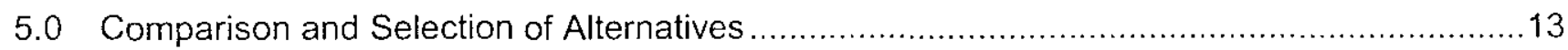

5.1 Evaluation Criteria and Considerations ........................................................ 13

5.2 Deployment Schedules for Alternatives ........................................................ 14

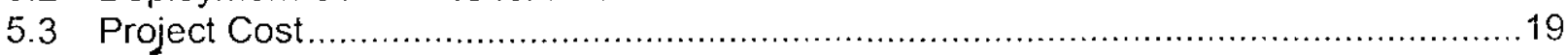

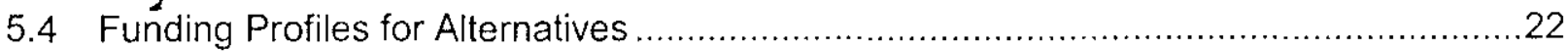

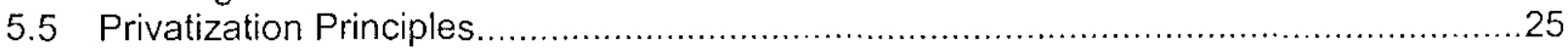

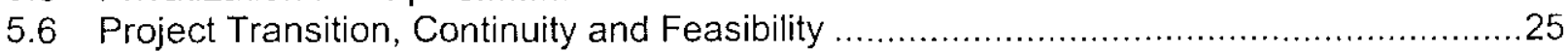

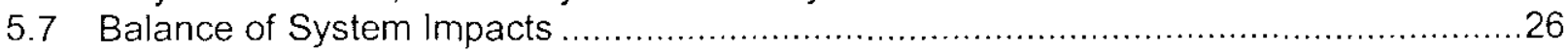

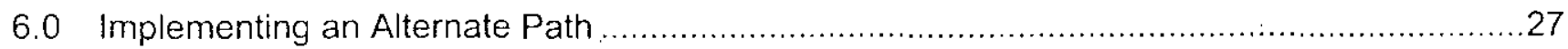

6.1 Relationship of Failure Mode to Alternative Selection .......................................27

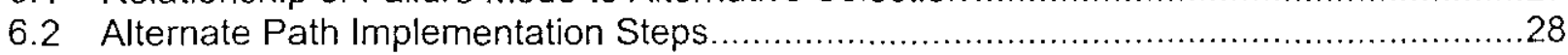

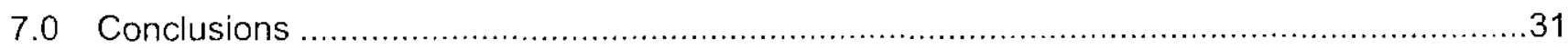

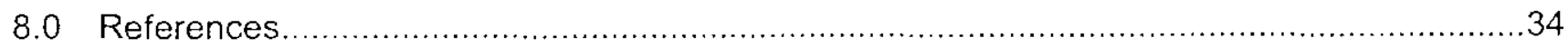

Appendix A Technical Alternatives to Reduce Risk in the Hanford Phase I Tank Waste

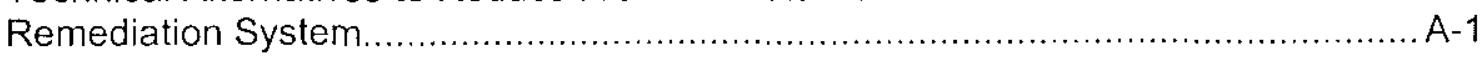

Appendix B Summary of Financial Variations in the Reference Privatization Approach .............. B-1

\section{Figures}

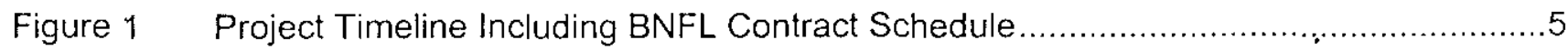

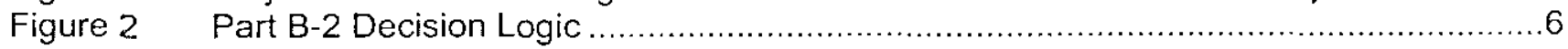

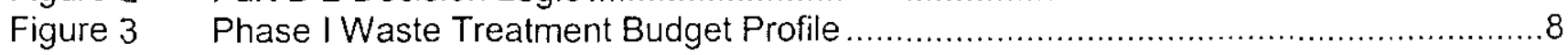

Figure 4 Schedule for Current Privatization Approach with BNFL: "Contract Case" and

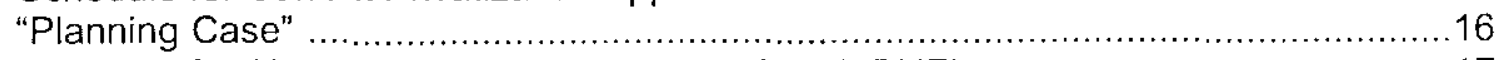

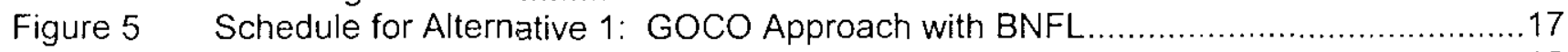

Figure $6 \quad$ Schedule for Alternative 2: GOCO Approach with a New Contractor .......................18

Figure $7 \quad$ Schedule for Alternative 3: Privatization Approach with a New Contractor................19

Figure 8 Comparison of Potential Cost Growth Impacts on Total Project Costs .....................22

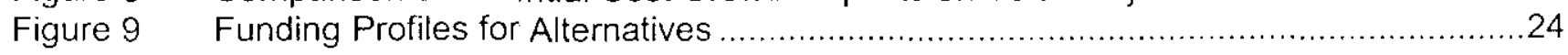

\section{Tables}

Table 1 Potential Applicability of Alternatives to B-2 Authorization Failure Modes ...................27

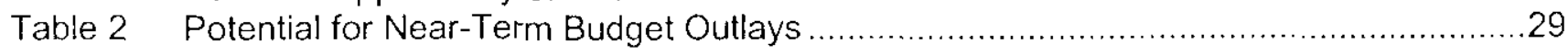


DOE/ORP-2000-04

Revision 0

\subsection{Introduction}

The U.S. Department of Energy (DOE) is currently planning to retrieve, pre-treat, immobilize and safely dispose of 53 million gallons of highly radioactive waste currently stored in underground tanks at Hanford Site. The DOE plan is a two-phased approach to privatizing the processing of hazardous and radioactive waste. Phase I is a proof-of-concept/commercial demonstration-scale effort whose objectives are to: demonstrate, the technical and business viability of using privatized facilities to treat Hanford tank waste; define and maintain required levels of radiological, nuclear, process and occupational safety; maintain environmental protection and compliance; and substantially reduce life-cycle costs and time required to treat Hanford tank waste. The Phase I effort consists of Part A and Part B. On September 25, 1996 (Reference 1), DOE signed a contract with BNFL, Inc. (BNFL) to commence with Phase I, Part A

In August 1998, BNFL was authorized to proceed with Phase 1, Part B-1, a 24-month design phase that will provide sufficient engineering and financial maturity to establish fixed-unit prices and financing terms for tank waste processing services in privately-owned and -operated facilities. By August 2000, DOE will decide whether to authorize BNFL to proceed with construction and operation of the proposed processing facilities, or pursue a different path.

To support of the decision, DOE is evaluating alternatives to potentially enhance the BNFL tank waste processing contract, as well as, developing an alternate path forward should DOE decide to not continue the BNFL contract. The decision on whether to continue with the current privatization strategy (BNFL contract) or to pursue an alternate can not be made until the evaluation process leading up to the decision on whether to authorize BNFL to proceed with construction and operation (known as the Part B-2 decision) is completed. The evaluation process includes reviewing and evaluating the information BNFL is scheduled to submit in April 2000 , and negotiating the best mutually acceptable contract terms. The alternatives studies completed to-date are summarized in Reference 2. 


\title{
2.0 Purpose
}

In November 1999, the Secretary of Energy and DOE committed to start hot operations for Hanford tank waste treatment by the year 2007, and complete treatment of 10 percent of the tank waste and 25 percent of the radiological activity by the year 2018 . To support the commitment, the proposed changes to the Hanford Federa! Facility Agreement and Consent Order or Tri-Party Agreement (TPA) included the submittal of this report as the following interim milestone (Reference 3):

\begin{abstract}
Submittal of Hanford Tank Waste Treatment Alternatives Report, 3/01/00. DOE will submit a report that describes the alternatives (technical, financial, and contractual) to treat Hanford tank waste. The report will: 1) identify and describe credible alternatives to the current privatization approach that meet DOE commitments to achieve hot operations by 2007, and to treat no less than 10 percent of the tank waste by volume and 25 percent of the tank waste by activity by the year 2018,2$)$ serve as a basis to amend the Fiscal Year 2001 budget request for authority to implement a contingency option (authority to use privatization set-aside funds), and 3) be released concurrently to Ecology, EPA, and the public.
\end{abstract}

This report provides the tank waste treatment alternatives that could be implemented if DOE decides not to proceed with the current privatization approach (BNFL contract).

This report focuses on the credible financial and contractual alternatives. Information is provided on the near-term budget impact of implementing alternatives including the potential budget authority and budget outlay changes needed in Fiscal Year (FY) 2001. Preliminary analyses are provided on the impact of changing some of the financial parameters, however, whether the current privatization approach or some other alternative would be the "best value" to the government, will be determined after the BNFL work products are delivered in April 2000. The best value analysis and other more detailed analyses of alternative financial structures will directly support the Part B-2 decision.

The technical alternatives evaluated in this report are consistent with the Tank Waste Remediation System (TWRS) Environmental Impact Statement (EIS) Record of Decision (ROD), and result in the same end-states for the waste. A broader set of technical alternatives were previously presented in Technical Alternatives to Reduce Risk in the Hanford Phase I Tank Waste Remediation System Project (Reference 4). The technical report concluded that the Phase I project is based on fundamentally sound waste treatment strategies and principles; and that the technical risks will be satisfactorily addressed as development work and design efforts progress. The report also recommends additional technology development tasks to further reduce the risk and guarantee project success. The tasks are enhancements to the current technical baseline rather than significantly different technical alternatives. Appendix $A$ provides a summary of Reference 4. 
DOE also examined technical alternatives that would be implemented if the current privatization approach could not be funded (Reference 5). However, none of these alternatives that meet the constrained budget also meet the emerging TPA framework; several fall outside the bounds of the current TWRS EIS ROD; and some would violate national policy and regulations.

Therefore, to address the TPA commitments that describe credible technical alternatives, DOE will rely on the results of the two recent studies (References 4 and 5) and will not further examine technical alternatives. 
DOE/ORP-2000-04

Revision 0

\subsection{Background}

\subsection{Current Privatization Approach}

Tank waste treatment is being carried out in two phases. Phase I will treat at least 10 percent of the waste and 25 percent of the radioactivity by 2018 . Phase II will treat the remaining waste. DOE decided to privatize the tank waste treatment effort using the following key principles:

- $\quad$ DOE acquires waste treatment services, not facilities and equipment from the Contractor,

- Contractor develops, designs, finances, constructs, operates, and deactivates the facilities; Contractor owns the facilities,

- $\quad$ DOE pays fixed-unit price upon delivery of products that meet specifications; actual budget outlays are deferred,

- DOE and the Contractor share the risks but the Contractor will retain significant performance risk, and

- DOE provides cost-saving incentives (e.g., improved performance yields increased profits and reduced DOE costs).

In 1996, DOE awarded a contract to BNFL for Phase I tank waste-treatment services. In August 1998, DOE authorized BNFL to proceed with the 24-month Part B-1 Design Phase. In August 2000, BNFL will transition from the Part B-1 Design Phase to the Part B-2, Construction and Operations Phase, if DOE approves. DOE approval is contingent on: 1) BNFL facility and operations proposal meeting DOE criteria (April 24, 2000, delivery date); 2) Successful negotiation on all aspects of Part B-2. by June 24, 2000; and 3) Congress accepting the DOE recommendation to proceed by August 24, 2000.

Figure 1 provides the BNFL contract schedule established in August 1998. The schedule may be revised after submission of BNFL. Part B-1 deliverables in April 2000, and contract negotiations through August 2000. 
DOE/ORP-2000-04

Revision 0

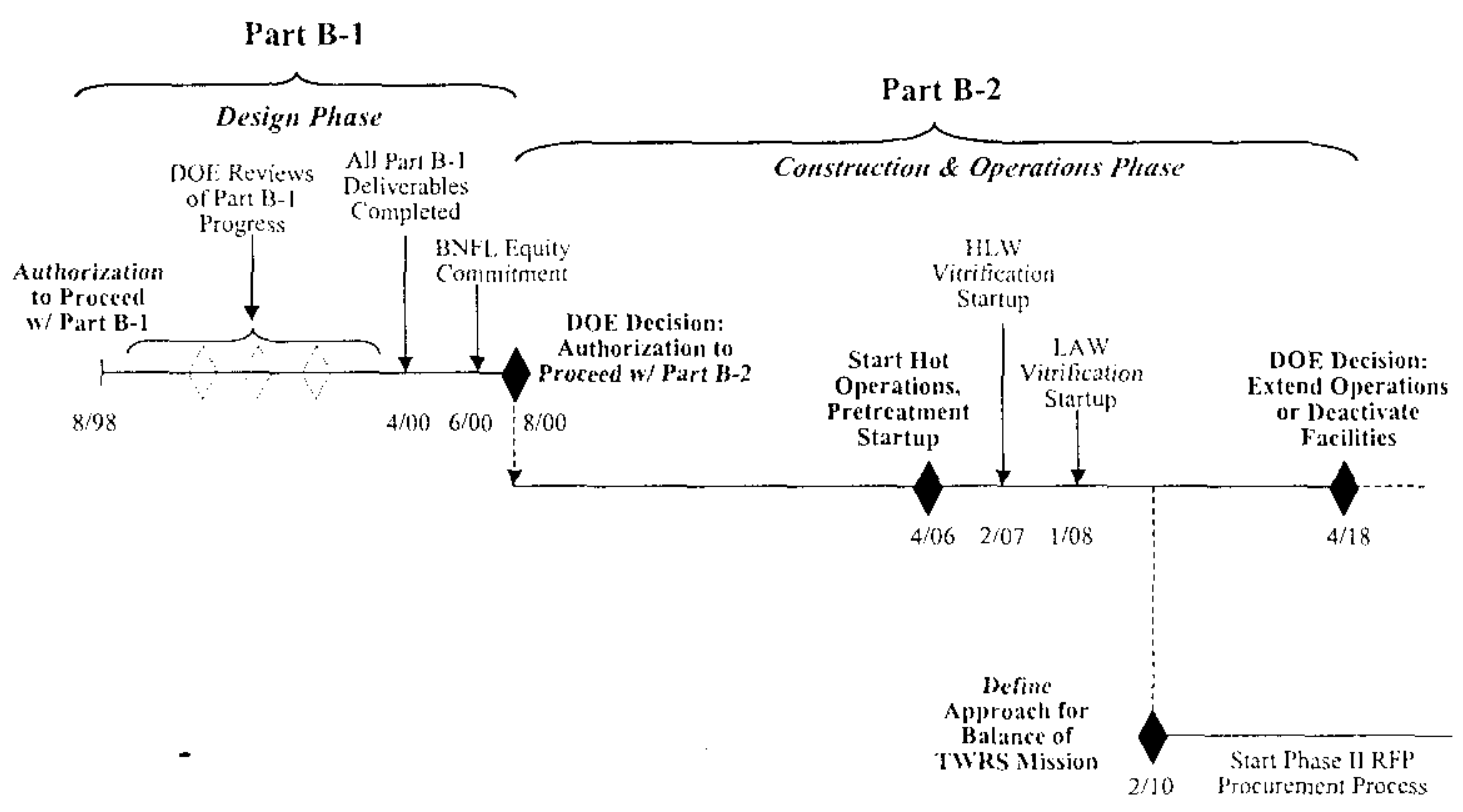

Figure 1. Project Timeline Including BNFL Contract Schedule

\subsection{Phase I, Part B-2 Decision}

At the end of Phase I, Part B-1, DOE will decide whether or not to authorize BNFL to proceed with Part B-2 of the contract. It is a key programmatic determination of whether to proceed with $B N F L$, or to pursue a different approach for acquiring tank waste remediation services at the Hanford Site. The acceptability of the BNFL proposal and conditions for Part B-2, including price, schedule, achievement of financial closure, and assurance of safety, and performance during Part B-1 will be significant in the decision-making process. In addition to the BNFL requirements, the DOE decision to authorize Part $B-2$ requires:

- A final, positive assessment of the other Hanford Site contractors' readiness to provide needed infrastructure and services, supply waste feed to BNFL, and accept immobilized waste products and secondary waste by-products,

- $\quad$ The DOE (Headquarters, Office of River Protection and Richland Operations Office) readiness to manage and integrate the BNFL and $\mathrm{CH} 2 \mathrm{M}$ HILL Hanford Group, Inc. (CHG) contracts,

- $\quad$ The DOE Office of Safety Regulation of the TWRS Privatization Contractor (Regulatory Unit) ability to regulate the BNFL facility (i.e., radiological, nuclear and process safety, and occupational safety and health),

- A determination that the contract terms and conditions represent the "best value" as compared to other alternatives and that the programmatic and contractual risks of proceeding are acceptable, and

- A determination by an external independent review that all aspects of the project are ready to proceed. 
DOE is currently evaluating input and preparing for the final decision. The Part B-2 decision will consist of one of the following four outcomes:

1. Proceed to Part B-2 using the current privatization strategy by contracting with BNFL,

2. Proceed to Part B-2 with BNFL, but with a modified contracting strategy,

3. Terminate the BNFL contract and implement an alternate path, or

4. Extend the Part B-1 design phase.

The BNFL contract includes a provision for extending the Part B-1 design phase and postponing the Part B-2 decision for up to nine months, to complete financial closure. At the end of the extension, the Part B-2 decision process will resume.

The Part B-2 decision will be made by the Secretary of Energy and documented for review by Congress.

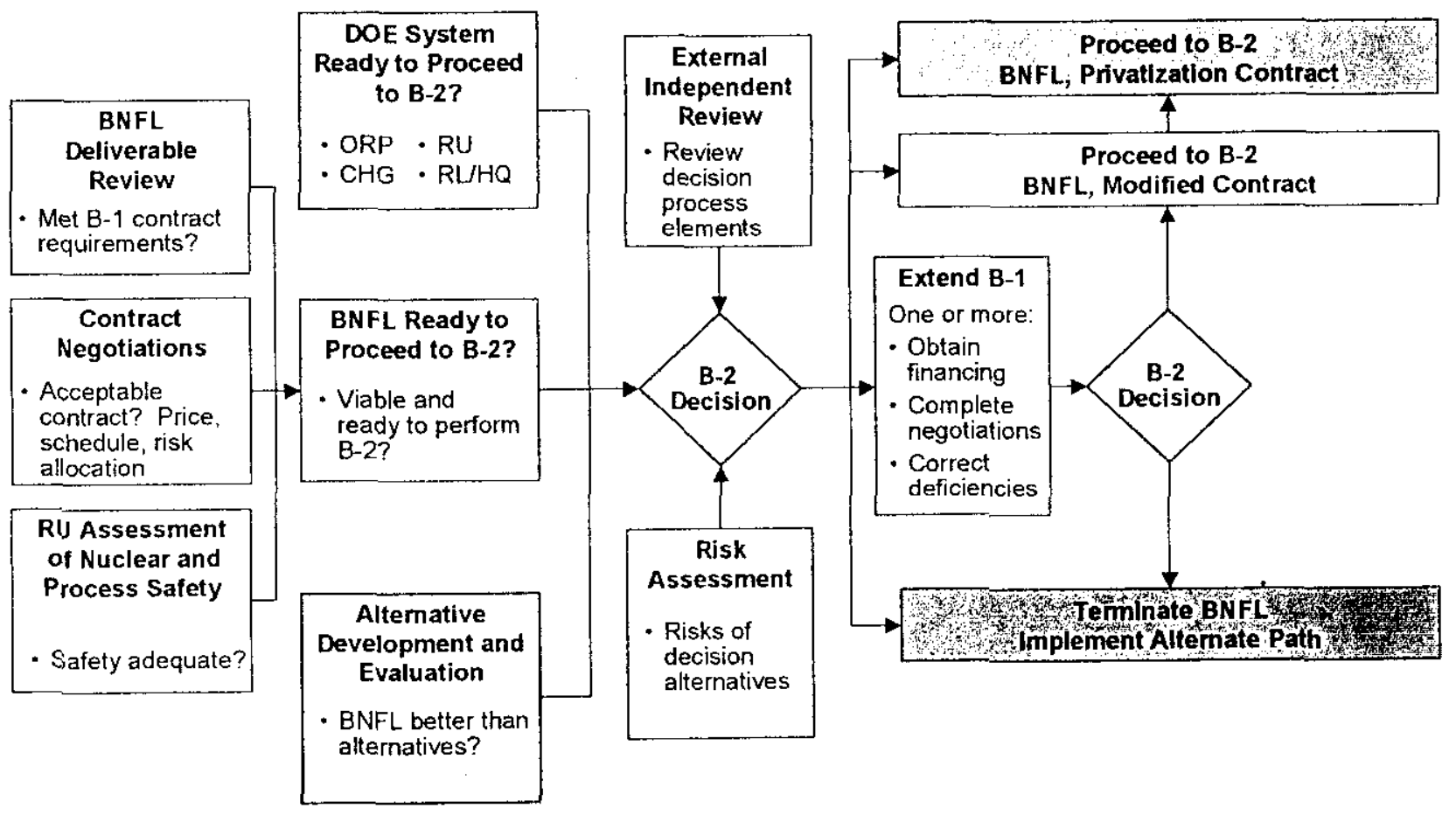

Figure 2. Part B-2 Decision Logic 
Figure 3. Phase I Waste Treatment Budget Profile

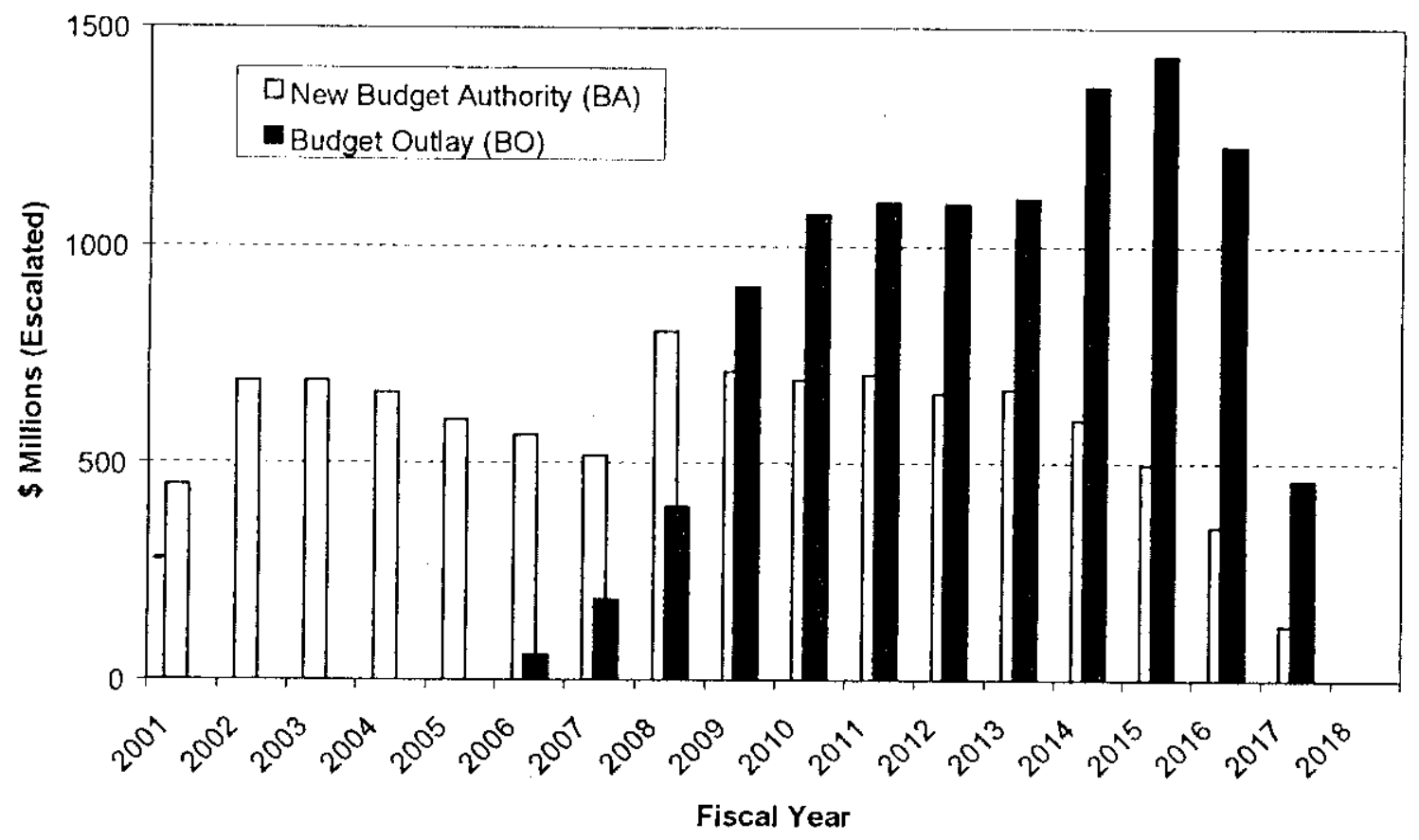




\subsection{Alternatives Development and Definition}

\subsection{Planning Assumptions}

To make the Part B-2 decision, DOE must identify and describe "credible alternatives to the current privatization approach." For purposes of this analysis, DOE assumes that all alternatives meet the same technical and performance specifications as the current privatization approach (BNFL contract). Phase I processing requirements remain the same for all alternatives. Alternatives to the current approach include cases, in which contractor ownership of a facility is not pursued, or the BNFL contract is terminated and another contractor takes over the project.

For alternatives that terminate the BNFL contract, it is assumed that:

- $\quad$ DOE and Congress will fund the contingency alternative that is selected.

- $\quad$ DOE will pay BNFL for the Phase 1, Part B-1 work in accordance with the contact terms and conditions.

- DOE will obtain all necessary intellectual property rights and deliverables from Phase 1, Part B-1 work, as prescribed by the BNFL contract.

- DOE will negotiate a termination settlement agreement that acquires additional . intellectual property rights deemed of merit to subsequent design activities.

- $\quad$ DOE will decide not earlier than June 24, 2000, and not later than August 24, 2000 , to terminate the BNFL contract.

Because the Phase I, Part B-1, 24-month design phase work is still in progress and the DOE decision on whether to authorize BNFL to proceed is several months away, reasons for failure of the present plan are hypothesized. For purposes of this report, "failure" is defined as a condition that prevents DOE from authorizing BNFL to proceed with Phase I, Part B-2 under the current privatization approach. The following failure modes are included as potential triggering events that DOE may need to respond to by implementing a contingency alternative.

Failure Mode 1: $\quad$ DOE terminates the contract due to BNFL non-performance during Part B-1. This failure would occur if BNFL does not meet Part B-1 contractual requirements. The decision would result from review of Part $\mathrm{B}-1$ deliverables.

Failure Mode 2: $\quad$ DOE terminates the contract because BNFL is not ready or able to perform Part B-2. This failure could be triggered by judgments in any one of several areas including technical performance, environmental permitting, safety, business/finance, and management. 
Failure Mode 3: $\quad$ BNFL is unable to obtain the necessary private financing. In this failure mode, neither of the prior two failure modes occurred and BNFL was directed to obtain financial closure, but are unable to obtain sufficient private financing.

Failure Mode 4: $\quad$ BNFL and DOE can not negotiate mutually acceptable contract terms. Inability to negotiate a mutually agreeable contract could be caused by many possible differences, but a plausible cause could result from unacceptable allocation of project risks between BNFL and DOE.

Failure Mode 5: $\quad$ Privatization does not prove to be cost-effective. The BNFL cost and schedule could increase or the expected cost and schedule for contracting alternatives could improve.

Failure Mode 6: $\quad$ DOE is unable to demonstrate readiness to proceed. Prior to authorizing Phase I, Part B-2, DOE and the Hanford Site contractors must demonstrate readiness and capability to manage the Phase 1, Part B-2 contract, to deliver waste feed and to accept the waste products. DOE readiness will be independently assessed.

Alternatives will be considered that could provide a contingency for each of the six Failure Modes listed above. However, at this time a determination can not be made whether the current privatization approach will fail, and, if so, by what failure mode. Most BNFL Part B-1 deliverables will not be available for review until April 2000. In addition, final evaluations, negotiations, and financial closure are not scheduled to commence until April 24, 2000.

\subsection{Description of Alternatives}

This section describes the current privatization approach with BNFL and three primary alternatives. For some of the alternatives, variations are also briefly described. The current privatization approach is included to provide a common point of comparison for the remaining alternatives.

Reference: Privatization Approach with BNFL. The current privatization approach assumes that BNFL builds a privately owned waste treatment facility and delivers waste products for a fixed price, i.e., Contractor-Owned Contractor-Operated (COCO) approach. The current privatization approach assumes that the privately owned facility is financed with $10 \%$ BNFL equity and $90 \%$ private debt financing. Two variations in the project financing approach are also available.

1. Finance Option A assumes that the privately owned facility is financed with $10 \%$ BNFL equity, $45 \%$ private debt financing, and $45 \%$ government financing.

2. Finance Option B assumes that the privately owned facility is financed with $10 \%$ BNFL equity and $90 \%$ government financing. 
Many other variations in the mix of private and government financing are possible, but those chosen provide a reasonable bounding for the current analysis. A more extensive set of financial studies is being conducted to support contract negotiations, financial closure, and the best value assessment. The studies are examining the magnitude and timing of equity funding and the mixture of recourse and non-recourse debt (i.e., with and without government credit support) among many other issues. The studies will support development of the best possible financial arrangement for the current privatization approach with BNFL. Because the financial variations modify or enhance the current privatization approach and do not respond to possible failures, the discussion is included in Appendix B. Appendix B presents an overview of the primary considerations encompassed by this work including some preliminary results. Final results from the analyses will not be available until after DOE and BNFL complete the Part B-2 decision process. However, Finance Options A and B, can respond to a potential failure in the current privatization approach (i.e., Failure Mode 3, BNFL is unable to obtain the necessary private financing). The two variations of the current privatization approach are carried forward through the remainder of this report.

Alternative 1: Government-Owned Contractor-Operated Approach with BNFL. This alternative would convert the BNFL contract to a traditional contract to complete the design of a government-owned contractor-operated (GOCO) facility. The conversion could occur through contract negotiation between DOE and BNFL and would not require a new competitive procurement. Allowable Part B-1 costs would be reimbursed. The contract conversion would be initiated by August 2000 to enable design activities to continue with minimal interruption. Following design, DOE could use one of several contract mechanisms (e.g., cost-plus incentive fee, fixed-price incentive fee, or even competitive procurements) to complete construction and operation of the facility. The goal would be to include competition points and incentive structures to maintain the current schedule. This alternative could be implemented through an incremental series of fixed-price contracts that seek to retain strong incentives for contractor performance. Changing the project approach to acquire a government-owned asset causes numerous differences in the acquisition process, including the approval/decision processes that must be applied, specifically, the requirements of DOE Order 430.1, Life Cycle Asset Management.

Alternative 2: Government-Owned Contractor-Operated Approach with a New Contractor. This alternative would change the contract mechanism to acquire a GOCO facility and would use a contractor other than BNFL to perform the design. Subsequent construction and operation activities could be performed by the new contractor or could be subcontracted through a competitive process. Similar to Alternative 1, DOE could use fixed price incentive contracts or other mechanisms to maintain strong incentives for contractor performance. There are two principal variations to this alternative:

a. Transfer to an existing Hanford Site contractor.

b. Transfer to a new contractor acquired through a competitive procurement. 
DOE would take possession of BNFL design products through a termination settlement, and would transfer the products to the new contractor. The new contractor would then be responsible for generating a new design, but would likely build upon the BNFL design. As with Alternative 1, different contract mechanisms would be available for the various stages of the project, including fixed-price incentive fee, and cost-plus incentive fee. The selection of the specific contract mechanism could be made at a later time.

Alternative 3: Privatization Approach with a New Contractor. This alternative would terminate the BNFL contract and then initiate a procurement action to obtain a new privatization contractor. Similar to Alternative 2, DOE would obtain the rights to BNFL design products through the termination settlement. The materials would be made available to prospective bidders for the contract. This alternative would retain the basic elements of the current privatization approach, including contractor-owned facility and government payment for product. 


\subsection{Comparison and Selection of Alternatives}

This section compares the merits of the alternatives and describes them relative to the reference alternative (current privatization approach with $B N F L$ ). The analysis is not intended to select the best alternative. The latter assessment will be completed after BNFL deliverables are received and negotiations are completed for fixed prices and other relevant contract terms. The focus of this comparison of alternatives is on relative merits in providing a contingency in case of a failure in the current privatization approach with BNFL. This section evaluates the implementation schedules, near-term funding profiles, and other factors that could affect DOE's ability to implement a contingency alternative in a timely manner.

\subsection{Evaluation Criteria and Considerations}

The following criteria (or considerations) are used to compare the alternatives:

- $\quad$ Schedule. This criterion is the primary basis for comparing the alternatives. Point estimates for each of the four key milestone dates were made (Section 5.2) and a qualitative discussion of potential variability in actual schedule achievement is provided. The projected start of construction indicates how quickly a transition could be made to the alternative. This is a strong discriminator among the alternatives and strongly affects several other comparison factors (e.g., project continuity).

- Project Cost. This criterion addresses the potential project cost and tendencies for cost growth that could be introduced by changes in project financing and contracting approaches. The changes can alter the strength and nature of contractor incentives to achieve cost and schedule performance goals. A more complete cost analysis of the reference and alternatives will be performed as part of the best value assessment that supports the Part B-2 decision.

- Near-Term Funding. This criterion addresses the near-term funding requirements (budget authority and budget outlay) required through 2010 , providing a measure of the "fundability" for the alternative. Separate project funding profiles were generated for each alternative using the same financial model that is used to support detailed analyses of the impacts of alternative financial assumptions associated with the BNFL contract.

- Privatization Principles. This criterion considers the retention of key principles of the current privatization approach, particularly pay for product, private facility ownership and contractor performance risk. The concepts are desirable in alternatives due to the strong performance incentive for the contractor. Other contract mechanisms can retain some aspects of the original plan. 
DOE/ORP-2000-04

Revision 0

- $\quad$ Project Transition, Continuity and Feasibility. This criterion examines the issues associated with transitioning and retaining the project. Some alternatives would threaten project continuity and others would run the risk of proceeding down a path with significantly increased deployment risks (e.g., threat of protests or lengthy procurement actions). At the present, a significant design team is in place with BNFL and a delay in the project could adversely affect the content.

- Balance of System Impacts. This criterion considers the impact of schedule changes on the rest of the Hanford Site, especially tank farm operations (tank space), single-shell tank (SST) waste retrieval schedules, safety, etc. Typically, longer delays in processing waste will delay the time when waste can be retrieved from SSTs. Also, the longer the project is extended, the longer the tanks will be used beyond design life.

\subsection{Deployment Schedules for Alternatives}

This section dëscribes the schedules for each alternative and the underlying assumptions. All schedules are derived from, and described relative to, the BNFL contract schedule established in August 1998 (hereafter called the "Contract Case"). The schedule is subject to revision after submission of BNFL Part B-1 deliverables in April 2000, and with contract negotiations through August 2000. The following assumptions apply to the schedules:

- The BNFL contract schedule is used as a starting point for building schedules for all of the alternatives because this is supported by the most detailed design work to date. Creating an independent schedule for a less developed alternative would likely produce an overly optimistic schedule and one that is less credible than the BNFL schedule. For example, the BNFL contract schedule for construction and operation is assumed to be the best that a GOCO contractor could achieve.

- $\quad$ For alternatives that must restart design efforts at some stage prior to the current BNFL stage of maturity, it is assumed that the design period required to reach the current design maturity will be similar to that required by BNFL. For example, if a new contractor must restart Part B-1, then it will take 24 months to complete Part B-1 (to attain a 25\%-30\% design).

- $\quad$ Funding will be sufficient and available in time to support each schedule. In some cases, this will require conversion of set-aside funds to provide budget outlays to support initiation of a contingency alternative.

- $\quad$ Any National Environmental Policy Act (NEPA) work needed to support contract changes can be performed concurrently with design and procurement without further impacting the schedule.

The assumptions lead to schedule estimates that represent what DOE believes is possible to achieve. However, any change to an alternative can encounter significant risks during the transition, including funding availability, procurement delays, or erosion of political support. Some of the risks are discussed in Section 5.6. Because of the risks, any of the alternatives could experience schedule delays in excess of that shown in this section. 
DOE/ORP-2000-04

Revision 0

Each of the schedules is compared to the following proposed TPA milestones (Reference 3):

1. Start of Construction -- Phase I Treatment Complex (7/31/01). First placement of structural concrete at one of the treatment complex principal facilities (i.e., pretreatment, low-activity waste vitrification, or high-level waste vitrification facilities).

2. Start (Hot) Commissioning -- Phase I Treatment Complex (12/2007). DOE will start hot commissioning of the tank waste treatment complex (defined as first principal facility receipt of radioactive tank waste for treatment).

3. Start Commercial Operation -- Phase I Treatment Complex (12/2009). DOE will achieve sustained throughput of pretreatment, low-activity waste (LAW) vitrification and high-level waste (HLW) vitrification processes, and demonstrated treatment complex availability to complete treatment of no less than 10 percent of the tank waste and 25 percent of the activity by 2018 .

4. Complete Phase I -- Treatment (12/2018). DOE shall complete treatment of no less than 10 percent of the tank waste and 25 percent of the activity.

The letter designations are consistent with the schedules shown in Figures 4-7. The figures identify separate segments for design, construction, and operations. The design period is assumed to start with a conceptual design comparable to BNFL starting point for Part B-1. The end of the design period is assumed to be the latest design activity of the three major processes, pretreatment, LAW vitrification, and HLW vitrification. The construction phase commences with Construction Authorization and extends through completion of Cold Testing and Readiness Reviews for the latest of the three processes. Because the three processes commence operations at different times, the construction and cold start schedule bar overlaps with the operations phase. The Operations Phase commences with the earliest hot start (i.e., pretreatment hot start) and ends with completion of the Contract waste quantity $(10 \%$ of the tank waste and $25 \%$ of the activity). The schedules do not include Deactivation.

\section{Reference: Privatization Approach with BNFL}

Figure 4 identifies the "Contract Case" schedule and the "Planning Case" schedule for BNFL. The four proposed TPA milestones are also identified. The "Contract Case" schedule is the schedule committed to by BNFL in the Contract. The "Contract Case" schedule forms the base input for business and finance models and for price determination and represents a $90 \%$ confidence level. DOE believes that the BNFL contract includes strong incentives to achieve the "Planning Case" schedule. The "Planning Case" schedule is used by BNFL to control the project and measure performance, and represents a $50 \%$ confidence level. For purposes of this report, the "Contract Case" schedule is used as the benchmark for comparing alternatives. Both schedules meet the four proposed TPA milestones. 


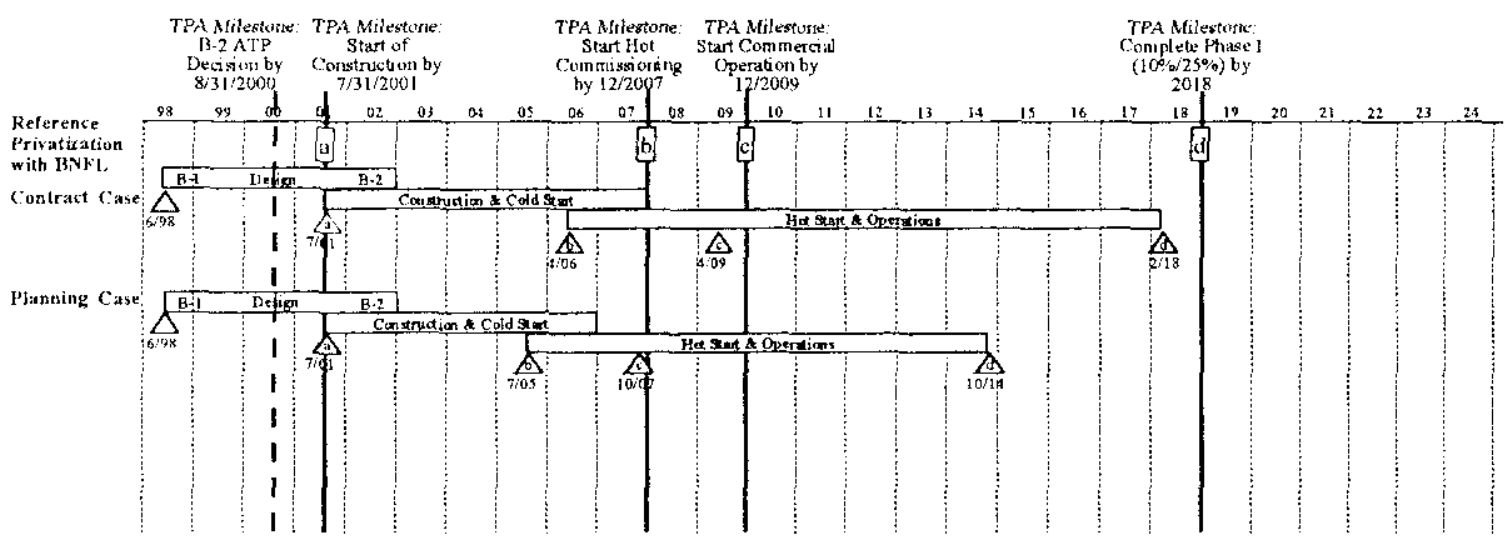

Figure 4. Schedule for Current Privatization Approach with BNFL:

"Contract Case" and "Planning Case"

The Contract Schedule applies to Finance Options A and B. The variations in financing approach do not affect the deployment schedule for this alternative. However, providing government financing would require actual budget outlays during project construction. The outlays are not currently authorized in the DOE budget and would be scored against the DOEEM budget cap.

\section{Alternative 1: GOCO Approach with BNFL}

Figure 5 provides the schedule for Alternative 1, GOCO approach with BNFL. Changing the BNFL contract to a more traditional contract mechanism means that DOE would be acquiring a GOCO facility. The change in ownership of the asset and shift of performance risk to DOE cause principal schedule changes relative to the current privatization approach. In converting the BNFL contract to a GOCO approach, the project would proceed as a major system acquisition and would progress sequentially through various phases. Start of construction could be delayed by 12 months, to July 2002 . The durations for subsequent construction and operations activities are assumed to be identical to those currently in the BNFL contract.

The schedule would require schedule performance much better than is typical of DOE major system acquisitions. The dotted extensions on the chart show milestone achievement more typical of historical experience. For example, The U.S. General Accounting Office (GAO) study Department of Energy: Opportunity to Improve Major System Acquisition (Reference 7) stated that projects were completed an average of 72 months behind schedule. In 1998, Bums and Roe, Inc. DOE M\&O Contractor Cost Estimate for the Hanford Tank Waste Remediation System Phase $1 B$, estimated the cost and schedule for performing the Phase I privatization work scope using a traditional DOE contract mechanism (Reference 8). The Burns and Roe, Inc. study estimated that the Phase I work scope would require about 58 months longer for completion under a traditional contract mechanism. Since the two studies were completed, DOE initiated efforts to reform contracting practices. As of this date, the results are not available for projects as large and complex as the Phase I project, but it is expected that through use of performancebased mechanisms, including fixed price incentive contracts, significant improvements from historical averages would result. 


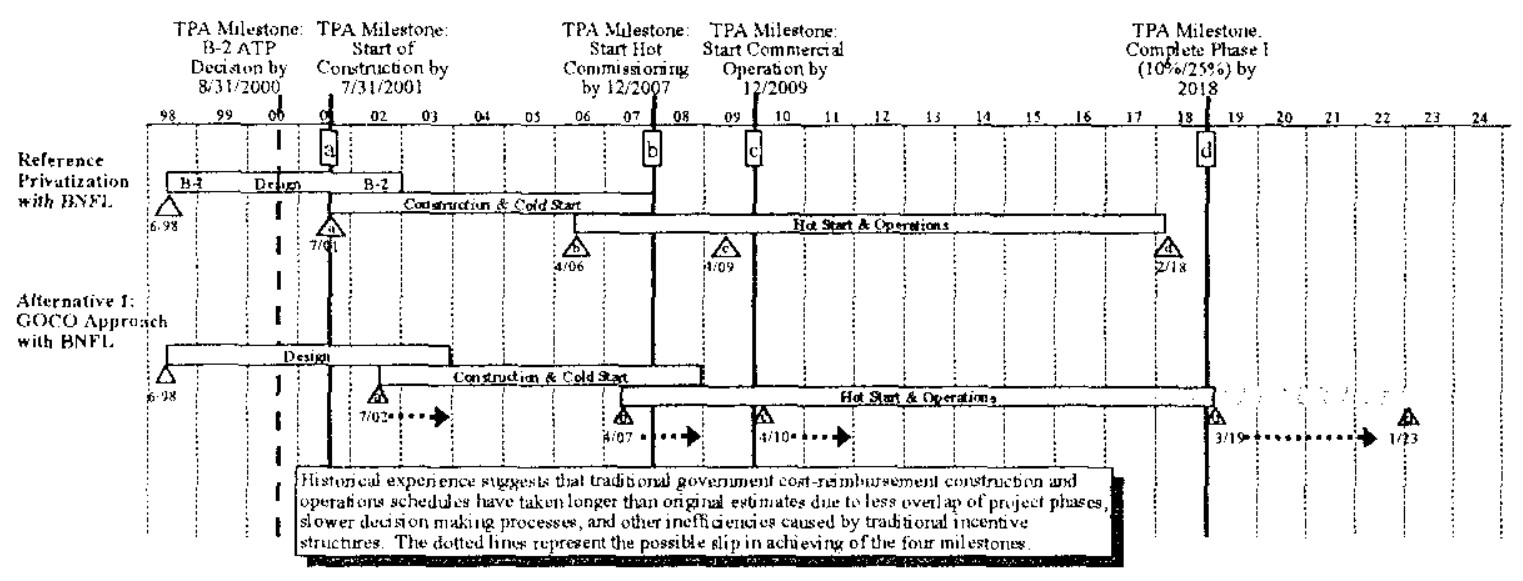

Figure 5. Schedule for Alternative 1: GOCO Approach with BNFL

The primary assumptions used to construct the Alternative1 schedule, include:

- The BNFL contract will be converted to a GOCO approach in FY 2000 and the change will require DOE-Headquarters approvals. The BNFL allowable Part B-1 costs will be reimbursed from the privatization account. The approvals necessary for contract conversion will slow progress and delay completion of design activities.

- $\quad$ Additional project information will be needed by DOE-Headquarters to support project decisions. BNFL will be required to provide some new and modified efforts and products. Efforts would be made to complete incremental requirements (e.g., an Independent Cost Estimate) concurrent with BNFL design efforts.

- $\quad$ Funding will be made available in FY 2000 and FY 2001 to maintain design continuity. Budget outlays will be required to fund design work after August 2000. The privatization account would be redirected to this effort for the balance of FY 2000 to allow continuity of design. A reprogramming will be prepared and submitted for FY 2001 budget requirements. Some portion of FY 2001 funding may be provided by conversion of privatization account funds, but for purposes of this analysis, funding will be available to implement the revised BNFL contract.

- $\quad$ The facility design will need to be more complete and construction packages better defined prior to receiving approval for procurement and construction activities. For a project of this size and complexity, it is typical to divide the start of construction approval decision into multiple decisions. This action allows the procurement of long-lead time equipment and some construction to proceed well ahead of completion of design for the entire facility. Nevertheless, additional design work would be required to support the start of construction decisions under Alternative 1. 
- The current contract team will be retained to construct the facility and DOE will structure contract incentives to achieve a construction schedule identical to that in the current BNFL contract.

- Similarly, DOE will use innovative contract incentives during facility operations to achieve performance equivalent to that in the current privatization approach.

\section{Alternative 2: GOCO Approach with a New Contractor}

This alternative is similar to Alternative 1 except that a contractor other than BNFL would lead the project. Figure 6 provides the schedules for Alternative 2 compared with the current privatization approach (BNFL contract) schedule. Assuming that the contract is transferred to an existing Hanford Site contractor, Alternative $2 \mathrm{~A}$, the schedule is identical to Alternative 1 except for an additional 6-month delay in start of construction (to January 2003). The delay represents an estimate of the time required to transfer BNFL design products and allows the new design contractor to resume design activities. All other schedule components are identical to those derived for Alternative 1.

The schedule presumes that the work can be transferred to an existing contractor, or team of contractors, available to readily absorb the existing design work and proceed immediately to complete the design. It also assumes that termination settlement with BNFL can be finalized promptly in FY 2000 and that the agreement would facilitate transfer of any additional intellectual property from BNFL to the new design team. It is possible that many of the personnel from the BNFL design team would be able to transition to the new contractor team.

A variation of Alternative 2 includes obtaining a new contractor by a competitive procurement, Alternative 2B. A separate schedule for Alternative 2B is provided as Figure 6 that includes a one-year delay for the new procurement process. The delay would result in losing the current design team and the new contractor would most likely resume design work at an earlier stage of Part B-1, in order to assume responsibility for the design and its eventual performance (assumed to be an additional six month delay). Therefore, as shown in Figure 6, if a new contractor is obtained through a competitive procurement, the project would be delayed 3 years compared to the baseline.

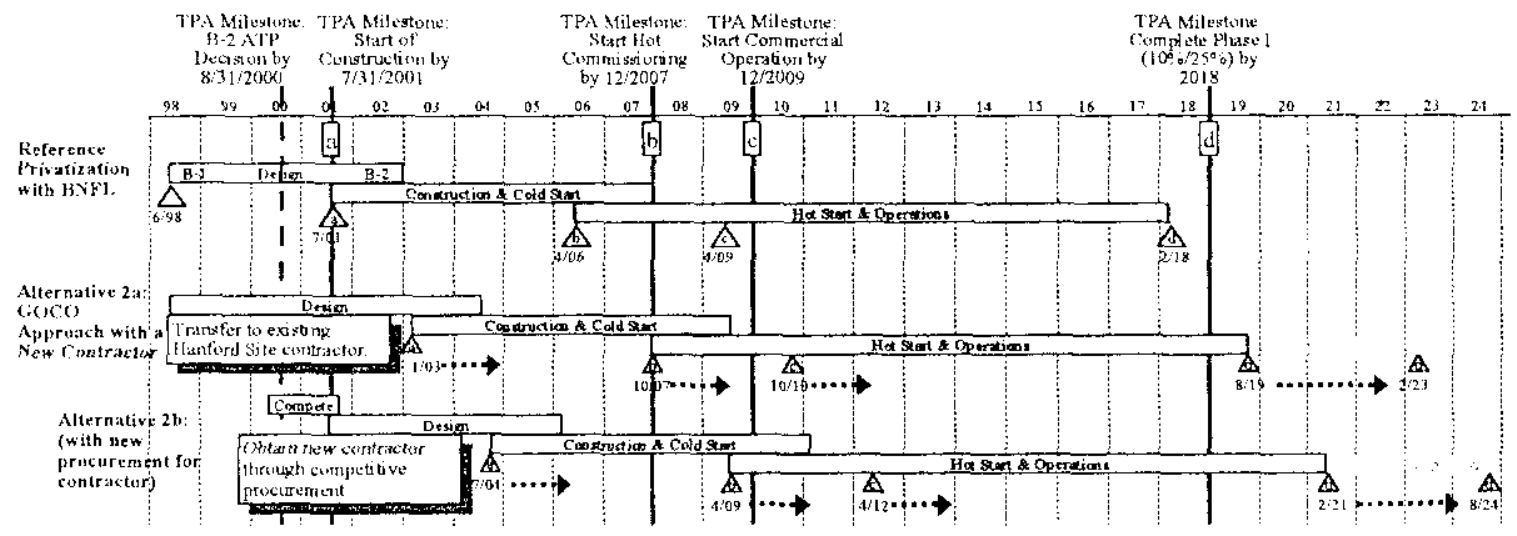

Figure 6. Schedule for Alternative 2: GOCO Approach with a New Contractor 


\section{Alternative 3: Privatization Approach with a New Contractor}

Figure 7 provides the Phase I schedule for a new privatization contractor. The schedule elements and durations are assumed to be identical to those in the BNFL contract. The only difference between the two schedules is caused by the delay period required to carry out a procurement for a contractor (assumed to require one year, June 2000-June 2001). The next key assumption for Alternative 3 is the stage of design maturity when the design activity resumes. A new privatization contractor is unlikely to accept the BNFL design. For the schedule, the new contractor would start at a point equivalent to the start of Part B-1, a loss of an additional two years in the design schedule. Therefore, the start of construction and the balance of the project would slip 3 years.

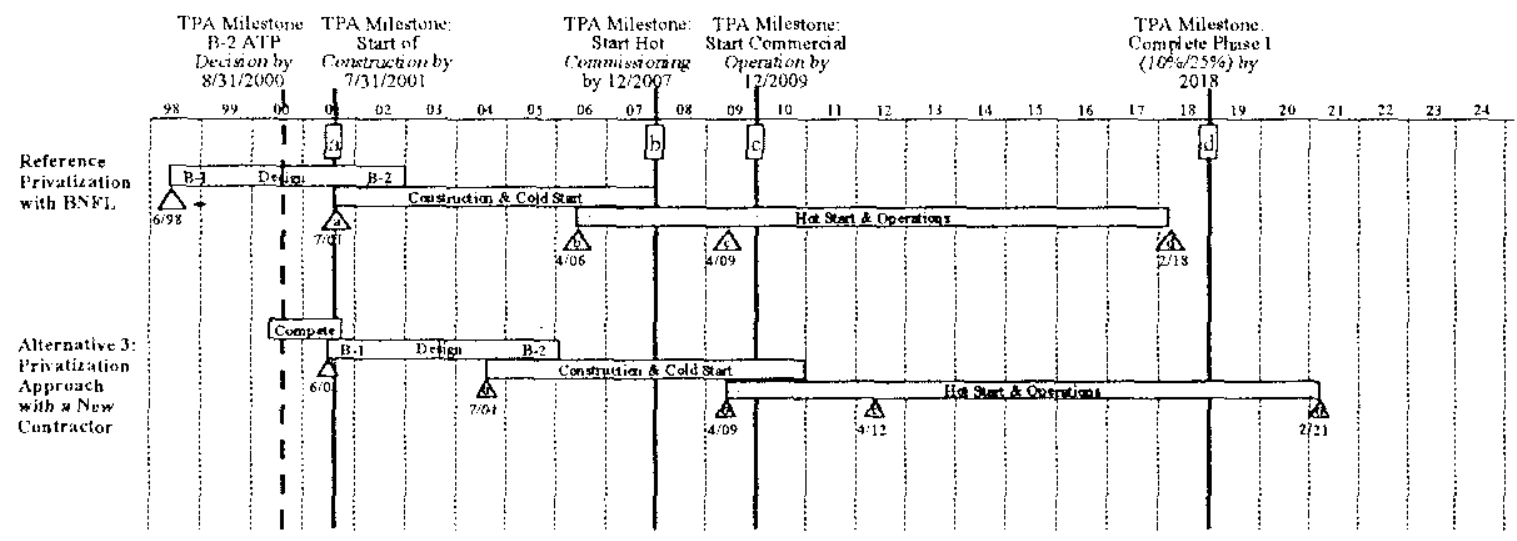

Figure 7. Schedule for Alternative 3: Privatization Approach with a New Contractor

\subsection{Project Cost}

This section describes the potential project costs that could result from the alternatives described in this report. The best value assessment will perform a more complete cost analysis in support of the Part B-2 decision. Separate cost estimates were not made for all of the alternatives. Rather, all cost estimates were derived from the existing 1998 cost estimate for the BNFL contract (Reference 9). The alternative contracting and financing mechanisms are overlaid upon the BNFL costs to provide a point of comparison. A central issue in this comparison is the potential for cost growth that would result from the various contracting and financing mechanisms.

To place alternative contracting and financing approaches on a common basis for comparison, it is necessary to account for differences in costs due to project ownership, taxes, and costs of financing. The methodology for comparing costs is similar to that described in the, Report to Congress - Treatment and Immobilization of Hanford Radioactive Tank Waste (Reference 9), which also compared the target costs of the Phase I project with other possible contracting approaches. The specific adjustments include: 
- Payment of federal taxes. Under privatization, the contractor will have a greater potential for profit and federal taxes will be paid on that profit. Therefore, the net cost to the government of the alternatives with privately owned facilities must account for the taxes that would be returned to the U.S. Treasury. For all alternatives, a credit is assumed for federal taxes returned to the treasury. Thus, profits, less tax payments, are shown for all cases and reflect a net cost to the government. A tax rate of $35 \%$ is assumed for all alternatives. Actual tax payments could differ depending upon the tax treatment BNFL receives from the U.S. Internal Revenue Service regarding rules for depreciation.

- Government cost of financing. The cost of private financing is reflected in the private contractor fixed prices. For a traditional GOCO approach, the government finances the project, but the true cost to the taxpayer of government financing is typically not included in cost estimates. It usually is reflected in how the Office of Management and Budget (OMB) scores the project. An equitable comparison of privately financed and government financed projects must account for the real cost of government financing to support budget outlays for government financed projects. Therefore, a charge (real interest rate of $3.5 \%$ ) is calculated for all alternatives that include government financing.

- Impact of contract incentives on cost growth. Privatization relies on a powerful set of incentives, including fixed priceș, private financing, and equity funding, that tend to reduce the potential for cost growth compared to traditional contract mechanisms. The privatization contractor has a much greater potential for profit, and loss, because of the incentives. Because the contractor bears a significant performance risk, DOE expects that the potential for cost growth will be substantially less than that experienced with traditional contracts.

There is no generally agreed upon method to predict the cost growth that could result from alternative contracting and financing mechanisms (for example, see Reference 10). Historical experience provides some insight into the potential for cost growth that could result from a large, complex project. For example:

- The GAO examined 80 major system acquisition projects conducted by DOE (Reference 7) and found for the projects that were completed, there was an average $63 \%$ cost growth. The cost overruns were measured for the construction phase only.

- $\quad$ A Rand Corporation study of 52 very large projects (average cost $\$ 2$ billion and 4 years to build) found that publicly owned projects exhibited $33 \%$ greater cost growth than privately owned projects (Reference 11). This finding also resulted from only the construction phase of the projects.

- The Burns and Roe study (Reference 8) of the Phase I cost and schedule estimated that a traditional Management and Operations (M\&O) approach would be expected to cost $68 \%$ more than the privatization approach (not including return on equity and finance costs for the privatization contract). 
Recently, DOE reformed its contracting practices to improve the performance incentives applied to contracts. However, there is little experience to date with new incentive structures applied to large design and construction projects.

While obtaining an accurate estimate of future cost growth is not possible, it is possible to determine how much cost growth would cause one or more alternatives to result in the same total project cost as the current privatization approach (BNFL contract). The "breakeven" cost growth rates were calculated for the different types of contract and finance mechanisms discussed in this report. Figure 8 provides the results of this analysis. Figure 8 also provides the cost that could result for a traditional cost-reimbursement contract assuming the $68 \%$ cost growth estimated earlier by Burns and Roe (Reference 8 ). To provide a fair basis of comparison, the results:

- $\quad$ Provide only after tax profit for all alternatives (show net cost to the government after payment of federal taxes),

- Include an imputed interest cost (at 3.5\%) for all alternatives that require federal financing,

- $\quad$ Assume that project schedules are identical to the current privatization approach, and

- Do not include any costs for project termination or transition.

The last two assumptions probably understate the cost of the alternatives relative to the reference.

As shown in Figure 8, if a traditional contract (represented by Alternatives 1 and 2) experiences greater than $35 \%$ cost growth, then the total cost would be greater than the current privatization approach. Historical experience suggests that actual cost growth could very likely exceed that amount. Finance Options A and B could potentially cost less than the reference, as shown in Figure 8. However, there is the potential that significant performance risk could be shifted to the government when there is shared financing ${ }^{(a)}$. If the resultant cost growth for Options $A$ and $B$ is more than the reference by $7 \%$ and $13 \%$, respectively, the options would cost more than the current privatization approach. The primary strength of the current privatization approach and Finance Options A and B is the impact of contractor equity commitment on the control of cost growth.

$\left({ }^{3}\right)$ Federal financing can be provided by payment of progress payments or milestone payments. These payments, however, can implicitly shift performance risk to the government. Also, Merrow (Ref. 11) found that for very large projects, those projects with shared public and private ownership experienced cost growth $25 \%$ greater than projects with public ownership alone. 


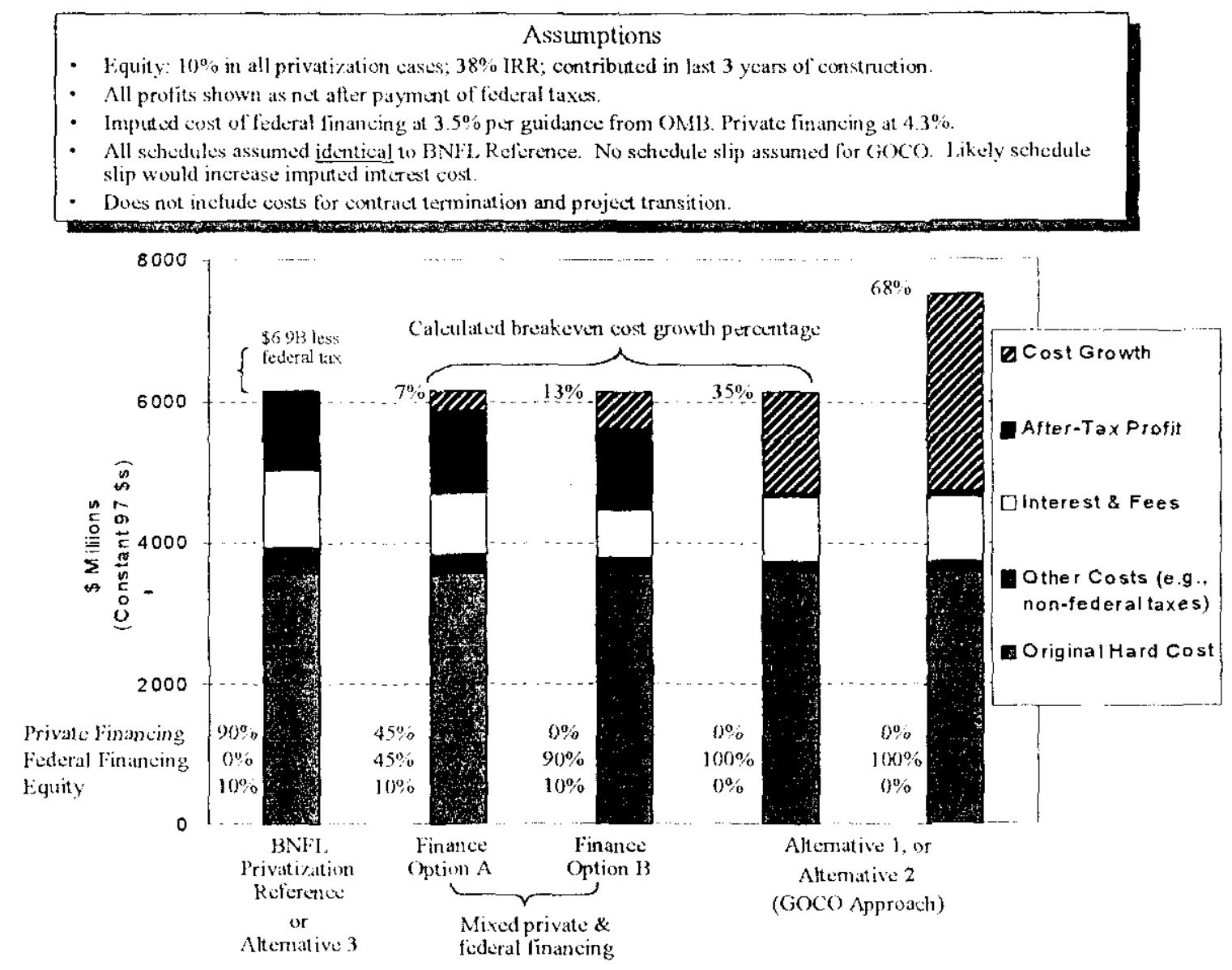

Figure 8. Comparison of Potential Cost Growth Impacts on Total Project Costs

\subsection{Funding Profiles for Alternatives}

Preliminary alternative funding profiles were generated to better understand differences in nearterm funding requirements. The profiles indicate how $B A$ and $B O$ would need to change in the crucial transition period to a new alternative. The estimates do not reflect a formal application of budget scoring rules, but rather are intended to show general differences inherent in the alternatives. The following assumptions were used to generate the $B A / B O$ profiles:

- $\quad$ All profiles were based on the BNFL design, spend profile and schedule.

- $\quad$ Budget profiles for GOCO approaches do not include the govemment cost of money ("imputed interest cost").

- Budget profiles for privatization contractors include interest charges for private financing.

- $\quad$ No adjustments were made for possible cost growth under alternate contract mechanisms. 
DOE/ORP-2000-04

Revision 0

- No incremental costs were added for new procurement activities.

- $\quad$ Costs were inflated using a $2.5 \%$ inflation rate.

- Construction and operations phase costs are identical to the BNFL reference (but adjusted for inflation).

- $\quad$ Cost to terminate the BNFL contract was not included, but would add to the total cost of each alternative (see Section 6.2).

Figures 9 (left column) provides the estimated BA/BO profiles for the current privatization approach and the two variations in financing, Finance Option A and Finance Option B. For both financing variations, budget outlays would be required to provide the federal share of the financing for design and construction of the facility. Near-term budget outlays would increase in direct relation to the proportion of federal financing that is used for the project. If the share is fairly low, then the impact could be relatively small, especially compared to the other alternatives.

Figure 9 (right column) also shows the BA/BO profiles for Alternatives 1, 2, and 3 .

- $\quad$ The profile for Alternative 1, GOCO Approach with BNFL, shows that a very significant increase in $\mathrm{BO}$, relative to the reference, would be required to support project continuation.

- The profile for Alternative 2, GOCO Approach with a New Contractor, shows a similar increase in immediate budget outlay. The profile is identical to that for Alternative 1 , except that it is shifted out in time depending on how quickly the transition could be made. The profile shown in Figure 9 corresponds to the first schedule in Figure 6 (transfer to existing Hanford Site contractor). If the new contractor is acquired through competitive bid, the profile would shift further to the right.

- $\quad$ Similarly, the profile for Alternative 3, Privatization Approach with a New Contractor, is similar to the BNFL reference in that no budget outlays would be required until much later in the project. The profile in Figure 9 reflects the 3 -year project delay.

Both Alternatives 1 and 2 require significant up-front budget outlay because the alternatives require full federal funding. However, Alternative 3 could use the existing $B A$ from the privatization account; but the $\mathrm{BO}$ is delayed 3 years from the current privatization approach. Compared to the other alternatives, there would not be as great a potential for funding delays. All other alternatives require significant increases in near-term budget outlays, which would be scored against the DOE-EM budget cap and would compete for priority with outlays needed for other EM projects. 
DOE/ORP-2000-04

Revision 0

\subsection{Privatization Principles}

Finance Options $A$ and $B$ of the current privatization approach retain most of the original privatization principles, particularly private equity commitment and payment for product. These would be distinct advantages relative to Alternatives 1 and 2. A possible disadvantage is that federal financing provided with progress payments (or milestone payments) could be interpreted as DOE acceptance of the BNFL design, transferring a significant portion of the performance risk to DOE. Contract terms would need to be negotiated to minimize this risk.

Alternatives 1 and 2, GOCO approach with BNFL or a new contractor, would shift most of the performance risk to DOE and will likely affect the project's total cost and schedule performance, (i.e., the potential for cost growth and schedule slippage increases). Contracting approaches that maintain strong incentives for contractor performance could potentially mitigate the adverse effects.

Alternative 3, Privatization Approach with a New Contractor, would retain the original privatization principles with the contractor bearing the performance risk. If multiple bidders respond, the approach could lead to additional competition.

\subsection{Project Transition, Continuity and Feasibility}

Finance Options $A$ and $B$ of the current privatization approach, face the risk of being unable to obtain federal financing for the project. Another possible difficulty would be the novelty of the mixed funding aspects of a privately owned facility. These factors could lead to project delay.

Alternative 1, GOCO Approach with BNFL, maintains the continuity of the design effort by maintaining the BNFL design team. It can support retention of knowledgeable staff with little disruption. There are three significant risks with the transition to this alternative: 1) obtaining authority for the budget outlays that are not currently planned in the DOE budget; 2) BNFL may not be willing to pursue the change; and 3) obtaining approval to convert the BNFL contract to a GOCO approach. On the latter point, it may not be in DOE's best interest to continue with BNFL; or the potential for protests from other suppliers could lead DOE to open the contract for competitive bid rather than directly converting the BNFL contract.

Alternative 2, GOCO Approach with a New Contractor, could maintain continuity of the design effort if the work can be quickly transferred to an existing on-site contractor. It can support retention of knowledgeable staff with little disruption although BNFL corporate expertise in HLW treatment would be lost to the project. There are two significant risks with the transition to this alternative: 1) obtaining authority for the budget outlays that are not currently planned in the DOE budget; and 2) making the transition to an existing contractor with out a competitive procurement. A competitive procurement, if required, would add another year to the front-end schedule and disrupt the continuity of the project, since the BNFL design team would disband.

Alternative 3, Privatization Approach with a New Contractor, would disrupt and delay the project. The delay from terminating the current effort to restarting a new effort would disrupt the current project team and expertise. Approximately $\$ 300 \mathrm{M}$ and four years of invested effort would be lost. Also, there may be no other capable and willing firm for a subsequent privatization venture. 
DOE/ORP-2000-04

Revision 0

\subsection{Balance of System Impacts}

Implementing an alternate path could affect the balance of the Hanford Site, primarily as a result of delaying waste treatment plant startup.

Finance Options A and B of the current privatization approach would have little or no impact as the schedule for the options would be identical or nearly the same as the current privatization approach.

Alternatives 1,2, and 3 result in tank waste treatment startup delays of one to three years. Waste treatment capability is needed to free up double-shell tank (DST) space and make it available to receive waste from SSTs and routine operations. DST space is adequate to complete SST interim stabilization and accommodate routine operations. However, any significant SST waste retrieval will be delayed until DST space is made available through waste treatment. The delay also extends the time that waste will remain in the tanks beyond design life and would increase the potential for tank leaks and adverse environmental impacts.

Several construction projects supporting the tank waste treatment effort will be affected. The projects provide infrastructure for the tank waste treatment plant, tank waste retrieval systems and transfer piping, and immobilized waste storage and disposal facilities. Depending on the length of the delay, it is likely that the projects under construction would be completed while those in design would be suspended. The work force and budgets would be affected accordingly. Also, the interface responsibilities would change if a new contractor is put in charge of deploying the tank waste treatment facilities.

Alternative 2, GOCO Approach with a New Contractor, could have a positive impact if that contractor was the same as the one operating the tank farms. Having one contractor for the entire project would eliminate a large number of interfaces and simplify management control. However, this is not significant enough to drive the selection of an alternative.

Implementing any of the alternatives can delay the project. Delays would slow the design effort and potentially diminish the value of prior Part B-1 work. Moreover, delays in waste treatment would extend the time required for maintaining tank farms and incurring essential costs to safely store existing tank waste. Approximately $\$ 200 \mathrm{M}$ to $\$ 250 \mathrm{M}$ is required annually to support ongoing tank farm management and operations, safety programs, characterization, and maintenance. The cost is incurred whether or not tank waste is retrieved and immobilized. Additional costs would also be incurred during a delay to maintain the capability to retrieve and deliver waste feed to a future waste treatment facility. 
DOE/ORP-2000-04

Revision 0

\subsection{Implementing an Alternate Path}

The section describes the relationship of possible failure modes with the alternatives, and the actions that would be taken to implement an alternate path. Emphasis is placed on the actions needed to ensure adequate funding for a new alternative during a transition period. A brief outline is also provided for the approval and procurement steps that would be required.

\subsection{Relationship of Failure Mode to Alternative Selection}

An alternate path will only be pursued if the current privatization approach fails. Because the information to understand which, if any, failure modes will occur will not be available until June 2000, this section summarizes a "what if" analysis. It describes the possible decisions that could result from the specific failure modes identified in Section 4.1. Some of the alternatives would not be vable responses to some failure modes. Table 1 summarizes the applicability of the alternatives to each of the identified failure modes.

Table 1. Potential Applicability of Alternatives to Part B-2 Authorization Failure Modes

\begin{tabular}{|c|c|c|c|c|}
\hline Failure Mode & $\begin{array}{l}\text { BNFL Reference } \\
\text { with Finance } \\
\text { Options A or B }\end{array}$ & $\begin{array}{l}\text { Alternative } 1: \\
\text { Goco Approach } \\
\text { with BNFL }\end{array}$ & $\begin{array}{l}\text { Alternative 2: } \\
\text { GOCO Approach } \\
\text { with a New } \\
\text { Contractor }\end{array}$ & $\begin{array}{c}\text { Alternative } 3: \\
\text { Privatization } \\
\text { Approach with a New } \\
\text { Contractor }\end{array}$ \\
\hline $\begin{array}{l}\text { Failure Mode 1: } \\
\text { DOE terminates the contract } \\
\text { due to BNFL non-performance } \\
\text { during Part B-1. }\end{array}$ & Not Viable & Not Viable & Acceptable & Acceptable \\
\hline $\begin{array}{l}\text { Failure Mode } 2 \text { : } \\
\text { DOE terminates the contract } \\
\text { because BNFL is not ready or } \\
\text { able to perform Part B-2. }\end{array}$ & Not Viable & Not Viable & Acceptable & Acceptable \\
\hline $\begin{array}{l}\text { Failure Mode } 3 \text { : } \\
\text { BNFL is unable to obtain the } \\
\text { necessary private financing. }\end{array}$ & $\begin{array}{l}\text { Acceptable } \\
\text { (but could depend } \\
\text { upon the exact } \\
\text { cause of failure) }\end{array}$ & Acceptable & Acceptable & - Acceptable \\
\hline $\begin{array}{l}\text { Failure Mode } 4 \text { : } \\
\text { BNFL and DOE cannot } \\
\text { negotiate mutually acceptable } \\
\text { contract terms. }\end{array}$ & Possible & Acceptable & Acceptable & Possible \\
\hline $\begin{array}{l}\text { Failure Mode } 5 \text { : } \\
\text { Privatization does not prove to } \\
\text { be cost-effective. }\end{array}$ & Possible & Acceptable & Acceptable & $\begin{array}{c}\text { Unknown } \\
\text { (other privatization is } \\
\text { not likely to be better, } \\
\text { few possible suppliors) }\end{array}$ \\
\hline $\begin{array}{l}\text { Failure Mode } 6 \text { : } \\
\text { DOE is unable to demonstrate } \\
\text { readiness to proceed. }\end{array}$ & $\begin{array}{c}\text { Extend BNFL } \\
\text { contract }\end{array}$ & $\begin{array}{l}\text { Acceptable } \\
\text { (pace of } \\
\text { deployment can } \\
\text { be matched to } \\
\text { DOE readiness) }\end{array}$ & $\begin{array}{l}\text { Acceptable } \\
\text { (pace of } \\
\text { deployment can } \\
\text { be matched to } \\
\text { DOE readiness) }\end{array}$ & $\begin{array}{c}\text { Possible } \\
\text { (only if delay to obtain } \\
\text { new contract improves } \\
\text { DOE readiness) }\end{array}$ \\
\hline
\end{tabular}


DOE/ORP-2000-04

Revision 0

In summary, Table 1 indicates that if Failure Modes 1 or 2 occur, BNFL would not be retained. Therefore, a new contractor would be required either using a GOCO approach contract or a new privatization contract. Similarly, if Failure Mode 4 occurs, a new contract form with BNFL or a new contractor would be needed. The finance options for the current privatization approach (BNFL contract) would be viable if Failure Mode 3 occurs and possibly if Failure Mode 5 occurs. If Failure Mode 6 occurs, an extension to the Part B-1 period could be implemented to retain the current privatization approach. Another approach would be to implement one of the other contract mechanisms, which would have greater flexibility to adjust schedules and plans to DOE readiness.

\subsection{Alternate Path Implementation Steps}

To implement any of the alternatives identified in this report, DOE will need to focus on three critical success factors:

- $\quad$ Obtaining the funding to support transition to and startup of the new alternative;

- $\quad$ Transferring the Part B-1 design assets and design team to the extent possible to allow use as a starting point for subsequent efforts; and

- Establishing the legal and contractual authority to implement the alternative.

Each of the topics is discussed below although the specific steps and timing for transition to a contingency alternative will depend upon the timing and nature of the failure mode that occurs.

If DOE decides to implement an alternate path (or contingency option), then the most critical factor in determining the timing and success of that path is likely to be the authorization of funding. Not all of the current budget authority for the current privatization approach can be applied to an alternate path. Termination of the BNFL contract (either through the selection of a different contractor or through a change in the contract type) will require that DOE use a significant portion of the available budget authority to cover termination costs, therefore, adding to the total cost of the alternative. To prepare for the possibility that the current privatization approach may fail, DOE will proceed with initial steps to convert the existing budget authority for use in an alternate path. Prior to the decision to terminate the BNFL contract, DOE will hold discussions with DOE-Headquarters, the OMB and U.S. Congress staff to develop a process for completing future actions required to reprogram the current budget authority to support an alternative. Concurrent with the preliminary discussions, DOE will prepare for the reprogramming.

Any reprogramming request must exclude the funds required to terminate the BNFL contract. The first step that DOE must take is to estimate the termination costs. Using documentation provided by BNFL for budgetary and contractual reasons, DOE would develop an estimate of the termination costs. Financing, budget and procurement personnel will review the termination estimate to ensure that all reasonable costs were included. 
In summary, Table 1 indicates that if Failure Modes 1 or 2 occur, BNFL would not be retained. Therefore, a new contractor would be required either using a GOCO approach contract or a new privatization contract. Similarly, if Failure Mode 4 occurs, a new contract form with BNFL or a new contractor would be needed. The finance options for the current privatization approach (BNFL contract) would be viable if Failure Mode 3 occurs and possibly if Failure Mode 5 occurs. If Failure Mode 6 occurs, an extension to the Part B-1 period could be implemented to retain the current privatization approach. Another approach would be to implement one of the other contract mechanisms, which would have greater flexibility to adjust schedules and plans to DOE readiness.

\subsection{Alternate Path Implementation Steps}

To implement any of the alternatives identified in this report, DOE will need to focus on three critical success factors:

- Obtaining the funding to support transition to and startup of the new alternative;

- $\quad$ Transferring the Part B-1 design assets and design team to the extent possible to allow use as a starting point for subsequent efforts; and

- $\quad$ Establishing the legal and contractual authority to implement the alternative.

Each of the topics is discussed below although the specific steps and timing for transition to a contingency alternative will depend upon the timing and nature of the failure mode that occurs.

If DOE decides to implement an alternate path (or contingency option), then the most critical factor in determining the timing and success of that path is likely to be the authorization of funding. Not all of the current budget authority for the current privatization approach can be applied to an alternate path. Termination of the BNFL contract (either through the selection of a different contractor or through a change in the contract type) will require that DOE use a significant portion of the available budget authority to cover termination costs, therefore, adding to the total cost of the alternative. To prepare for the possibility that the current privatization approach may fail, DOE will proceed with initial steps to convert the existing budget authority for use in an alternate path. Prior to the decision to terminate the BNFL contract, DOE will hold discussions with DOE-Headquarters, the OMB and U.S. Congress staff to develop a process for completing future actions required to reprogram the current budget authority to support an alternative. Concurrent with the preliminary discussions, DOE will prepare for the reprogramming.

Any reprogramming request must exclude the funds required to terminate the BNFL contract. The first step that DOE must take is to estimate the termination costs. Using documentation provided by BNFL for budgetary and contractual reasons, DOE would develop an estimate of the termination costs. Financing, budget and procurement personnel will review the termination estimate to ensure that all reasonable costs were included. 
DOE currently has $\$ 490 \mathrm{M}$ of budget authority for the BNFL contract ${ }^{(\mathrm{a})}$. In the event that DOE terminates the BNFL contract for convenience during FY 2000, but prior to financial closure, DOE would pay termination costs that could include:

- Part B-1 design costs (up to $\$ 250 M$ ),

- Interest on project costs (approximately $\$ 20 \mathrm{M}$ ),

- Rights to the BNFL pilot melter (approximately $\$ 40 \mathrm{M}$ ), and

- $\quad$ Fees for Part B-1 work performed (up to $\$ 50 \mathrm{M}$ ).

Therefore, contract termination could require up to $\$ 360 \mathrm{M}$, which would leave about $\$ 130 \mathrm{M}$ of budget authority that could be available for transition and startup of a contingency alternative, subject to U.S. Congress approval of a reprogramming request. An additional $\$ 450 \mathrm{M}$ in budget authority may be available to this project in the FY 2001 budget. Assuming that BNFL is retained through FY 2000 for project closeout and transition activities, DOE would seek to reprogram FY 2001 budget authority to support implementation of a contingency alternative. There would be approximately $\$ 575 \mathrm{M}$ remaining in the privatization account that DOE would attempt to convert for use in proceeding with the alternate path. A reprogramming request would be prepared by DOE and submitted to the U.S. Congress. The exact amount of the request will depend upon the selected alternative. Table 2 summarizes the potential for budget outlays in FY 2000 and FY 2001 for the current privatization approach and each of the alternatives.

Table 2. Potential for Near-Term Budget Outlays

\begin{tabular}{|c|c|c|}
\hline Alternative & $\begin{array}{l}\text { FY } 2000 \text { Potential Budget } \\
\text { Outlay }\end{array}$ & $\begin{array}{l}\text { FY } 2001 \text { Potential Budget } \\
\text { Outlay }\end{array}$ \\
\hline BNFL Reference & $\$ 50 M(a)$ & $\$ 0$ \\
\hline $\begin{array}{l}\text { BNFL. Reference with Finance } \\
\text { Option A }\end{array}$ & $\$ 50 M(a)$ & $-\$ 275 \mathrm{M}(\mathrm{c})$ \\
\hline $\begin{array}{l}\text { BNFL Reference with Finance } \\
\text { Option B }\end{array}$ & $\$ 50 M(a)$ & $\sim \$ 400 M(c)$ \\
\hline $\begin{array}{l}\text { Alternative 1, GOCO Approach } \\
\text { with BNFL }\end{array}$ & $\$ 360 M(b)$ & $\sim \$ 300 M(d)$ \\
\hline $\begin{array}{l}\text { Alternative } 2 \text {, GOCO Approach } \\
\text { with a New Contractor }\end{array}$ & $\$ 360 M(b)$ & $\$ 100 M-\$ 200 M(e)$ \\
\hline $\begin{array}{l}\text { Alternative } 3, \text { Privatization } \\
\text { Approach with a New Contractor }\end{array}$ & $\$ 360 M(b)$ & $\$ 0$ \\
\hline \multicolumn{3}{|c|}{$\begin{array}{l}\text { Notes: } \\
\text { (a) Maximum Part B-1 fee payments to BNFL } \\
\text { (b) Termination costs including Part B-1 costs, fees, and other commitments (including rights to the } \\
\text { BNFL pilot melter) } \\
\text { (c) Financing provided by federal government; requires reprogramming. } \\
\text { (d) Based on BNFL cost under privatization of }-\$ 360 \mathrm{M} \text { but assuming a reduced pace to support initial } \\
\text { transition to new contract mechanism; requires reprogramming. } \\
\text { (e) Exact amount depends upon the pace of transition to the new contractor; requires reprogramming. }\end{array}$} \\
\hline
\end{tabular}

(a) This total results from annual appropriations to the set-aside fund of $\$ 170 \mathrm{M}, \$ 115 \mathrm{M}, \$ 100 \mathrm{M}$ and $\$ 105.6 \mathrm{M}$ for FY1997 through FY 2000, respectively. Previously, $\$ 54 M$ was paid for work performed during Part A of this project, but this amount was paid from a separate fund and is not included in the present total. 
Another critical issue in implementing a contingency alternative will be preservation of the design team and design products from Part B-1. The expertise of the team and design products would be extremely valuable to any follow-on effort. One method that DOE could pursue if BNFL does NOT continue (Alternatives 2 and 3 ) would be to implement a Design Asset Preservation Program (DAPP) to transfer design assets from one contractor to another. The technique is used to build a solid base of design information when design activity is discontinued. It could be implemented prior to a Part B-2 decision, but could not be completed until after a decision to terminate the BNFL contract. Part of the termination settlement with BNFL would deal with the transfer of design assets essential to continuing the project. The activity would:

- $\quad$ Retain the existing design team and expertise to the extent possible.

- Capture current state of design (in all contractually mandated forms).

- Obtain disclosure of design tools, software, etc.

$$
-
$$

- $\quad$ Obtain supporting rationale for the preferred design approach.

- Obtain disclosure of the state of design and indicate work to be completed.

- Obtain disclosure of design elements that are equipment vendor specific.

- Identify equipment and construction specifications that are applicable to the design deliverables and design basis.

Activities necessary to obtain contractual authority will be unique to each of the alternatives addressed. For the mixed financing variations of the current privatization approach, a contract modification will be negotiated. The primary contractual issue will be the mechanism DOE will use to provide its' share of project financing (e.g., advance payments, progress payments, performance-based payments, etc.) For Alternative 1, DOE will need to modify the existing BNFL contract to contain terms consistent with government ownership of the facility. The change will require approvals from the Secretary of Energy, OMB, and the U.S. Congress. For Alternative 2, if DOE transfers the work to an existing Hanford Site contractor, the existing contract would need to be modified. Some existing Hanford Site contracts already contain a provision that would allow absorption of the current privatization approach work scope, in the event that DOE terminates the BNFL contract. If it is determined that a competitive bid process must be used, DOE will prepare a Request for Proposals (RFP) to support the procurement. Similarly, to implement Alternative 3, DOE will need to prepare a new procurement package, including a draft and final RFP. 
DOE/ORP-2000-04

Revision 0

\subsection{Conclusions}

This report identified and assessed alternatives to the current privatization approach that still accomplish the same work on, or as near to, the current schedule as possible. Should the current privatization approach fail, an alternate path can not be selected until the failure mode is identified. The failure mode is unlikely to be known until the June to August 2000-time period. DOE will continue to compare the current approach with other credible alternatives to ensure that the best path forward is selected. If DOE is unable to proceed with the current privatization approach, the analysis in this report will be refined to support contractual and financial changes and amend budget requests.

DOE considered the following alternatives to the current privatization approach:

Finance Options A and B - The two variations of the reference approach allow for partial federal financing of the project ( $45 \%$ and $90 \%$, respectively), and both retain $10 \%$ equity funding by BNFL.

Alternative 1, GoCo Approach with BNFL - This alternative would modify the BNFL contract to implement a GOCO approach that would use cost-reimbursement or fixedprice contract terms.

Alternative 2, GOCO Approach with a New Contractor - This alternative is similar to Alternative 1 except that a contractor other than BNFL would continue the project. There are two variations of this alternative: $2 \mathrm{~A}$ ) direct transfer to an existing Hanford Site contractor, and $2 \mathrm{~B}$ ) transfer to a new contractor through a competitive procurement.

Alternative 3, Privatization Approach with a New Contractor - This alternative would obtain a new privatization contractor through a competitive procurement.

The conclusions of assessment of alternatives are:

1. The number of credible alternatives is very limited and all result in delays in tank waste treatment.

A. Of the alternatives considered, two variations of the current privatization approach that combine federal and private financing (Finance Options $A$ and $B$ ) would have the best possibility of maintaining the current schedule. However, the approaches would place the schedule at risk by requiring immediate budget outlays, which are not currently available to this project.

B. Two other alternatives could potentially meet the proposed TPA 2007 hot commissioning milestone: continue with BNFL under a GOCO approach (Alternative 1); and transferring the project to an existing Hanford Site contractor under a GOCO approach (Alternative 2A). Both of the alternatives would also require immediate budget outlays, which are not currently available. 
C. Two additional alternatives that were considered (Alternatives $2 \mathrm{~B}$ and 3 ) could not meet the hot commissioning milestone. Both alternatives would obtain a new contractor through competitive bid (under a GOCO approach and privatization, respectively) and would limit project progress during the transition.

2. A key principle of the DOE tank waste treatment effort is to privately finance facility design and construction and defer actual budget outlays until the facility operates and produces acceptable products. Only Alternative 3, privatization approach with a new contractor, retains the principle. All other alternatives require immediate budget outlays. The authority to outlay money for the alternatives could be obtained by a reprogramming action (with U.S. Congress approval). However, the outlays would be within the DOE-EM current budget cap and would displace planned outlays for other projects within the DOE complex -- putting the project at further risk of delay.

3. Another key principle of the current privatization approach is that BNFL retains significant performance risk. BNFL corporate investment in the project (through $\$ 200 \mathrm{M}$ to $\$ 500 \mathrm{M}$ of equity funding) and commitment to deliver products for a fixed price represent powerful incentives that DOE believes will lead to cost and schedule performance that is much better than traditional contracting approaches.

A. Only Alternative 3, privatization approach with a new contractor, would maintain performance risk with the contractor, but only after a several year delay in the project.

B. The two variations of the current privatization approach (Finance Options $A$ and $B$ ) could lead to lower project cost by substituting relatively lower cost federal financing for private financing. However, shared financing leads to sharing of performance risk, which could weaken the performance incentive from BNFL equity investment.

C. Converting the project to a more traditional GOCO approach (Alternatives 1 and 2) shifts most of the performance risk to DOE. While DOE Contract Reform efforts make available performance-based incentive contract mechanisms, there is little experience with the mechanisms on projects of the complexity and duration of the current project. DOE believes that the best way to ensure good project performance is to retain private ownership and equity investment.

D. Providing waste treatment by a GOCO approach shifts most performance risk to the government. Historically, the shift of performance risk to the government has led to cost growth with these contracts that more than offsets the higher financing cost and profit of a privatization contract.

4. The loss of project continuity, particularly the loss of the design team, is of great concern. If the BNFL contract is terminated and there is a significant delay before the project is continued in some other manner, the design team will disband and the design work performed to date will lose value, since it will not be "owned" by the new contractor. This is of particular concern with Alternatives 2B and 3 that require new competitive procurements to select a subsequent contractor. 
5. Recent assessments determined that the baseline technology is fundamentaliy sound and no superior technical alternatives were identified. If a contingency alternative is needed, the current technical approach (phased deployment of vitrification technology) would be retained.

6. Impacts to the balance of the Hanford Site, caused by the delay in waste treatment plant startup, extend the time before waste can be removed from the DSTs. The DSTs have space enough to complete SST interim stabilization and routine waste receipts but can not accommodate SST waste retrieval. The delay extends the time that waste remains in tanks beyond the design life, and would increase the potential for future tank leaks. 
DOE/ORP-2000-04

Revision 0

\subsection{References}

1. U.S. Department of Energy. BNFL, Inc. TWRS Privatization Contract, Number DE-RP0696RL13308, Mod 012. January 24, 2000.

2. Office of River Protection. Summary of Hanford Tank Waste Processing Alternatives Studies. DOE/ORP-99-12, Revision 0, January 2000.

3. Agreement on Principal Regulatory Commitments Pertaining to Hanford Tank Waste Treatment Complex Construction and Operations. Agreement between U.S. DOE, U.S. EPA, and State of Washington Department of Ecology, November 15, 1999.

4. U.S. Department of Energy. Technical Alternatives to Reduce Risk in the Hanford Phase I Tank Waste Remediation System Project, U.S. Department of Energy Office of Environmental Management, Office of Science and Technology Tank Focus Area, DOE/EM-0493, September 1999.

5. Office of River Protection. Hanford Tank Waste Disposition Alternatives That Could Be Considered if Baseline Cannot Be Funded, DOE/ORP-99-03 Rev. 0, prepared by D.D. Wodrich, January 2000.

6. Office of River Protection. Part B-2 Decision Plan. January 14, 2000.

7. U.S. General Accounting Office. Department of Energy: Opportunity to Improve Management of Major System Acquisitions. GAO/RCED-97-17. November 1996.

8. Burns and Roe. DOE M\&O Contractor Cost Estimate for the Hanford Tank Waste Remediation System Phase IB. Prepared by Burns and Roe Enterprises, Inc. for the U.S. DOE Office of Field Management. June 1998.

9. U.S. Department of Energy. Report to Congress - Treatment and Immobilization of Hanford Radioactive Tank Waste. July 1998.

10. U.S. General Accounting Office. Nuclear Waste: DOE's Estimates of Potential Savings from Privatizing Cleanup Projects. GAO/RCED-97-49R, January 31, 1997.

11. Merrow, E.L. et al. 1998. Understanding the Outcomes of Megaprojects: A Quantitative Analysis of Very Large Civilian Projects. The Rand Corporation, R-3560-PSSP. 


\section{Appendix A}

\section{Technical Alternatives to Reduce Risk in the Hanford Phase I Tank Waste Remediation System}

A team of seven independent technical experts reviewed the higher risk portions of the Hanford Phase I technical baseline including the treatment and immobilization processes to be conducted by BNFL Inc. (BNFL) and the waste characterization, retrieval, staging, and transfer functions to be conducted by $\mathrm{CH} 2 \mathrm{M}$ HILL Hanford Group, Inc. (CHG). The team evaluated technical risks and identified technical alternatives for the high-risk portions of the current baseline. In the study, technical risk was defined as the probability that a unit operation would not perform as intended, multiplied by the consequences (cost and schedule impacts) to the project. The team recommended preferred technical alternatives and a prioritized list of new work to implement the preferred alternatives.

The team emphasized Phase I activities and associated end-states, and considered technology alternatives that could be implemented beyond Phase I. The team reviewed the currently proposed baseline flow sheets. Technical issues were evaluated based on whether they present a low, moderate, or high risk to the overall success of the project. Based on the number of technical issued identified and the risk evaluation, the team then assigned an overall technical risk to each unit operation. A detailed discussion of technology development needed to mitigate the risks for each unit operation is detailed in the report. Alternative technologies are identified and prioritized, recommended technology development activities, and defined highly ranked improvements and alternatives.

The team reached the following conclusions:

1. The Phase I project is based upon fundamentaliy sound waste treatment strategies and principles.

2. BNFL and Project Hanford Management Contract personnel (now CHG) performed an excellent job of identifying technical and programmatic risks and developing plans to resolve them.

3. At this early stage of the project, a number of technical risks still exist. From the information reviewed, it appears likely that all of the risks will be satisfactorily addressed as development work and design efforts progress. Therefore, Phase 1. Part B, as currently defined, has a very good chance of succeeding.

4. Of the technical risks identified by the team, two are rated high:
A. Strontium-90/transuranic element removal process - immature technology.
B. Sulfate removal technologies - a system-wide issue whose resolution will likely require a combination of approaches.

5. The vitrification effort, involving BNFL, GTS Duratek, and Catholic University, is a sound, well-integrated program. 
The recommendations for the overall technology development program, listed in priority order are as follows:

1. Complete all baseline technology development tasks

2. Develop additional sulfate removal processes

3. Develop strontium-90/transuranic element removal processes

4. Execute the in-tank mixer pump tests as soon as possible

5. Evaluate flammable gas release during mixer pump operation

6. Provide adequate analytical facilities

7. Test melters thoroughly

8. Develop alternative cesium-137 removal processes

9. Provide a bench scale integrated, radioactive processing facility

10. Deploy a large (9-liter) waste sampler

11. Perform a similar review at the end of Phase I, Part B-1 contract.

The team concluded that completing the additional development work for baseline verification, improvements to the baseline, and alternative processes, would further guarantee the success of this critical project. However, adequate resources must be provided to ensure timely completion of the key development activities. 


\section{Appendix B}

\section{Summary of Financial Variations in the Reference Privatization Approach}

An extensive set of financial studies is being conducted to support contract negotiations, financial closure, and the best value assessment. The studies focus on the current privatization approach with BNFL Inc. (BNFL) and examine the magnitude/timing of equity funding and the mixture of recourse and non-recourse debt (i.e., with and without government credit support, respectively) among many issues. The studies will support developing the best financial arrangement for the current privatization approach. This appendix presents an overview of the primary considerations, including some of the preliminary results. Final results from the analyses will not be available until the Part B-2 decision process is complete.

\section{B.1 Equity Commitment}

Equity represents the BNFL direct corporate investment in the success of the project. The BNFL equity investment will also be in a "first loss" position if the project should fail because of inadequate performance. This will provide the contractor with a strong motivation to succeed. The return actually realized on the investment will depend directly on the ability to design, construct, and operate a facility, in an efficient, cost-effective manner. Thus, the expected return on equity could be reduced significantly if the costs increase or their performance fails to meet expectations.

Amount of equity commitment. If the equity commitment is insignificant, the contractor will have limited motivation for successful project completion because the contractor has little to lose as a result of non-performance. The contract requires BNFL to commit between $\$ 200$ million $(M)-\$ 500 M$ of equity to the project. An equity commitment within this range should be large enough to motivate contractor performance without unnecessarily increasing the price of the project. For analysis purposes, U.S. Department of Energy (DOE) is assuming that the BNFL equity commitment will be about $10 \%$ of the project capital costs $(\sim 400 \mathrm{M}$ in nominal or escalated terms). Increasing the equity commitment will strengthen the incentive to perform, but will lead to higher fixed-unit prices because equity is the highest cost element of the finance mix.

Preliminary analysis results suggest that total project price is fairly sensitive to the amount of private equity invested.

- Total project price (escalated dollars) with $10 \%$ equity $(\sim 400 \mathrm{M})=-\$ 9.0$ billion (B)

- Total project price (escalated dollars) with $5 \%$ equity $(\sim \$ 200 \mathrm{M})=\sim \$ 8.3 \mathrm{~B}$

Project costs are shown in escalated dollars (assumed $2.5 \%$ escalation rate) and are net to the government after payment of federal taxes $(\sim \$ 1 \mathrm{~B})$. The corresponding project cost in constant 1997 dollars is $\$ 6.9 \mathrm{~B}$ or $\$ 6.2 \mathrm{~B}$ net after payment of federal taxes. 
Timing of equity funding. The current privatization approach requires that BNFL use its' equity to fund project costs starting with initiation of the plant-commissioning period, exhaustion of project capital funds, or default of the project, whichever is earlier. If the project proceeds as planned, equity will be "back-loaded" into the project (i.e., during plant commissioning). However, the BNFL equity is at risk as soon as private financing is obtained. In the event of project termination, DOE credit support would reimburse BNFL for private financing costs less the amount of BNFL equity commitment. Thus, the BNFL equity is in a first-loss position, as private lenders would seek to recover the investment from BNFL corporate resources.

A key issue in defining the nature of the BNFL equity commitment is the timing of equity funding. Equity could be used to fund the project at different points in time. For example, it could be "front-loaded" (i.e., during the first 2-3 years of Part B-2) or it could be funded on a "pro-rata" basis (10\% of all Part B-2 costs).

Preliminary analysis shows that total project cost is very sensitive to the timing of equity funding.

- $\quad$ Contract Reference Assumption, Back-loaded equity funding, Total project price $=\sim \$ 9.0 \mathrm{~B}$

- $\quad$ Pro-rata equity funding $=\sim \$ 12.5 \mathrm{~B}$

- $\quad$ Front-loaded equity funding $=\sim \$ 18.3 \mathrm{~B}$

All cost estimates are expressed in escalated dollars with $10 \%$ equity $(\sim \$ 400 \mathrm{M})$ and $38 \%$ before tax internal rate of return on equity, and net after payment of federal taxes.

DOE believes that back-loaded equity provides the best value because the total cost is reduced relative to other possible equity timing options. In addition, maintaining BNFL equity in a firstloss position from the beginning of project financing maintains a powerful performance incentive.

\section{B.2 Non-Recourse Debt (Class A Debt)}

Non-recourse debt is lent through the banks, capital markets and other lending institutions.

Payment of the debt is secured solely by the revenues, and the collateral package (expected to include liquidated damages, contingency reserves, process warranties, and other funds). The payment is non-recourse to BNFL as a corporation once equity is funded, and receives no support under the contract in the event of non-payment because of contractor fault. Lenders will focus solely on the cash flow and ability to meet debt service requirements. Lenders of this type of debt are first to receive project cash flows but do not have additional assurances for repayment of principal and interest (see Recourse Debt below).

The debt is in a "second-loss" position because, to the extent that revenues do not cover costs, the principal and interest will not be paid. Current project cost estimates assume that there is no Class A debt. The current contract requests that BNFL provide a "best effort" to seek NonRecourse debt, but it is not required. Initial discussions with financial institutions indicate that there is interest in providing Class A dept financing. Decisions on Class A debt need to address the amount of project funding provided through the mechanism, timing, and cost relative to Class B debt. 
Preliminary discussions with financial institutions indicate that for Class A debt, the interest rate spread over Treasury Rates could range from $2.3 \%$ to $6.0 \%$. Assuming that Class A debt is obtained in roughly the same proportion as BNFL equity $(-10 \%$ of the project's capital cost), total project price, relative to the reference (no Class A debt), could increase from about $1 \%$ to $3 \%$, depending on the actual interest rate spread that is attained. Greater amounts of Class $A$ debt would have a proportionally greater impact on project price.

Because the Class $A$ debt is at higher risk than Recourse Debt, the amount of oversight provided by the lenders of Class $A$ debt should be commensurate with the interest rate differential. Class A debt providers will be much more interested that the project is properly structured (i.e., the engineering, procurement, and construction contract, and the operations and maintenance arrangements are appropriate, and that the independent engineer's report indicates the project will be successful), that construction progress is commensurate with the funds being drawn, and that the facility can be completed within the remaining budget. In general, Class A debt providers are highly motivated to monitor the project to ensure a return of the principal and anticipated interest earnings.

\section{B.3 Recourse Debt (Class B Debt)}

The capital markets, banks and other lending institutions lend recourse debt. Also, as with nonrecourse debt, in the event the contractor has performance problems that increase the internal project costs, available sources of project funds (not money from the lender or DOE) would be accessed to fund necessary modifications to the project. Those sources normally would include liquidated damages, equipment and process warranties, contingency, and the contractor equity. The exact allocation between recourse and non-recourse debt, nature and amount of these sources will be determined during negotiations of the financing documents. However, recourse debt relies, in part, on the government commitment to support and/or take over ownership of the project after all contractor resources are depleted. If DOE determines that the contract should be terminated, the termination settlement would include, as an allowable cost for the contractor, the outstanding recourse debt. The provision of recourse debt will substantially reduce the interest costs associated with the project, and without the provision, the contractor is unlikely to be able to arrange project financing with any private lender.

Current planning assumptions set the share of Recourse Debt at $90 \%$ of project funding requirements. This share will vary depending on the amount of equity and Class $A$ debt that is provided. The cost of the financing will depend upon the debt rating for the project (expected to be AA or AAA) and is expected to range from about $0.75 \%$ to $1.5 \%$ above U.S. Treasury rates. The baseline project cost estimate assumes a $0.8 \%$ rate differential. 